\title{
Dergiabant
}

Cilt/Volume: 9, Sayı/Issue: 1

(Mayıs/May 2021)

\section{Eş'arîlik ve Mâtürîdîlik Arasındaki İhtilaflı Meselelere Bir Katkı: Kün Emri ve Yaratmaya Tesiri}

\section{A Contribution to the Controversial Issues Between the Ash'ariyya and the Māturīdiyya: The Order of Kun and It's Effect on Creation}

\author{
Hikmet Yağlı Mavil \\ Dr. Öğr. Üyesi, Bolu Abant İzzet Baysal Üniversitesi, İlahiyat Fakültesi, \\ Kelâm ve İslâm Mezhepleri Tarihi Anabilim Dalı \\ Asst. Prof. Dr., Bolu Abant Izzet Baysal University, Faculty of Theology, \\ Department of Kalam and History of Islamic Sects \\ Bolu/Turkey \\ hmavil@ibu.edu.tr \\ orcid.org/0000-0003-0251-5019

\section{$\underline{\text { Makale Bilgisi } \quad \text { Article Information }}$} \\ Geliş Tarihi: 24 Mart 2021 \\ Kabul Tarihi: 2 Mayıs 2021 \\ Yayın Tarihi: 30 Mayıs 2021 \\ Yayın Sezonu: Bahar \\ Article Type: Research Article \\ Date Received: 24 March 2021 \\ Date Accepted: 2 May 2021 \\ Date Published: 30 May 2021 \\ Publication Season: Spring \\ https://doi.org/10.33931/abuifd.902409 \\ İntihal/Plagiarism
}

Makale Türü: Araştırma Makalesi

Bu makale özel bir yazılımla taranmış ve intihal tespit edilmemiştir. This article has been scanned by a special software and no plagiarism detected.

\section{Atıf/Cite as}

Yağlı Mavil, Hikmet. "Eş‘arîlik ve Mâtürîdîlik Arasındaki İhtilaflı Meselelere Bir Katkı: Kün Emri ve Yaratmaya Tesiri”. Dergiabant 9/1 (Mayıs 2021), 64-94. https://doi.org/10.33931/abuifd.902409

Copyright $\odot$ Published by Bolu Abant Izzet Baysal University Faculty of Theology, Bolu, 14030 Turkey. All rights reserved. https://dergipark.org.tr/tr/pub/dergiabant 


\title{
Eş'arîlik ve Mâtürîdîlik Arasındaki İhtilaflı Meselelere Bir Katkı: Kün Emri ve Yaratmaya Tesiri
}

\section{Öz}

Semâvî dinler geleneğinde önemli bir yere sahip olan "söz-yaratma” ilișkisi, Kur'ân'da geçen "kün âyetleri" bağlamında ifadesini bulmuştur. Buna göre Allah, bir şeyi yaratmak istediği zaman "ol" demesinin yeterli olacağını, o șeyin de hemen oluverdiğini bildirmektedir. Allah'ın evreni yoktan yarattığı konusunda aynı kanaati paylaşan kelâm âlimleri, bu yaratmanın nasıl gerçekleştiği ve "kün" emrinin yaratmadaki rolü meselesinde ise ilahî sıfat anlayışlarına göre farklı görüşler ortaya atmışlardır. Ebû Hanîfe'den itibaren zatî sıfatlar ile fiilî sıfatlar arasında herhangi bir ayırım gözetmeyen ve yaratmayı tekvin sıfatı ile açıklayan Mâtürîdiyye âlimlerinin çoğunluğu, kün emrini “Allah'ın yaratmasının sürati”ni anlatan mecazî bir ifade kabul ederek ilgili âyetleri te'vil etme yoluna gitmişlerdir. Bazı Mâtürîdîler ise yaratmanın tekvin sıfatıyla gerçekleștiği düşüncesini göz ardı etmemekle birlikte âyetlerin lafzına bağlı kalarak kün emrinin de bir tür yaratma olduğunu düșünmüşlerdir. Diğer taraftan yaratmanın kudret sıfatı ile gerçekleștiğini kabul eden Eş'arîler, Ehl-i hadis âlimleri ile Küllâbiyye'nin izinden giderek kün emrini Allah'ın ezelî “yaratıcı söz”ü olarak değerlendirmişler ve bu konuda ispat yöntemini benimsemişlerdir. Bu bağlamda kün emriyle ilgili iki mezhep arasındaki ihtilaf, sadece kudret-tekvin tartışmasından ibaret olmayıp naslara yaklaşım konusundaki yöntem farklılığın bir yansımasıdır. Kudretten başka yaratıcı ezelî bir niteliği gerektirmesi, kelâm sıfatını lafız-mana ilişkisi dışında başka bir hususla ilişkilendirmesi gibi açılardan tenkit edilen Eş'arîlerin bu yaklaşımı, müteahhir dönemdeki bazı Eş'arî bilginleri tarafından kabul edilmemiştir. Söz konusu bilginler bu konuda Mâtürîdîlerin te'vile dayalı yaklaşımını benimsemişler, ancak yorumlarında onlardan farklı olarak kendi mezheplerinin yaratmayı açıklamak üzere başvurduğu "ezelî kudret" anlayışını muhafaza etmişlerdir. Bu makalede Eş'arîler ile Mâtürîdîler arasındaki "kün" emrine dayalı ihtilafın ayrıntıları ele alınmakta ve kelâm yöntemi açısından hangi yaklaşımın daha tutarlı olduğu belirlenmeye çalıșılmaktadır.

Anahtar Kelimeler: Kelâm, Eş'ariyye, Mâtürîdiyye, Kün (Ol) Emri, Tekvin.

\section{A Contribution to the Controversial Issues Between the Ash'ariyya and the Māturīdiyya: The Order of Kun and It's Effect on Creation}

\begin{abstract}
The "word-creation" relationship, which has an important place in the tradition of Abrahamic religions, has found its expression in the context of the "kun verses" in the Qur'ān. Sharing the same opinion about God's creation of the universe from nothing, theologians have different views on the issue of how this creation took place and the role of the command "kun" in creation, according to their understanding of divine attributes. Since Abū Ḥanīfa, most of the Māturīdiyya scholars, who did not make any difference between the personal and the actual attributes, thought that the attribute of takwin was necessary for the creation and they interpreted the related verses, thinking that the order of kun was an allegory from the speed of Allah's creation. But some of them did not ignore the idea that creation took place with takwin, but they also thought that the order of kun was a kind of creation, adhering to the apparent meaning of the verses. On the other hand, the Ash'ariyya scholars, who think that creation takes place with the attribute of qudra, and who do not make any distinction between takwin and mukawwan, regarded the order of kun as the eternal "creative word" of God. While the Māturīdiyya followed the method of ta'wīl in this issue, it is interesting that the Ash'ariyya applied the method of isbāt. Some of later Ash'ariyya scholars also criticized this approach and adopted the interpretation of the
\end{abstract}


Māturīdiyya on this issue. In this article, the details of the dispute between the Ash'ariyya and the Māturīdiyya based on the order of "kun" are discussed and it is tried to determine which approach is more consistent in terms of the method of kalām.

Keywords: Kalām, The Ash`ariyya, The Māturīdiyya, Order of Kun (Be), Takwīn.

\section{Giriş}

Arapçada "kevn" mastarının emir kipine karşıllk gelen "kün" (ol) kelimesi, kelâm ilminde Allah'ın eşyayı yoktan yaratmasını ifade etmek üzere kullanılan bir terimdir. ${ }^{1}$ Her şeyin bir sözle yaratıldığını anlatan ifadelere Kur'an'ın yanı sıra Tevrat, Zebur ve İncil gibi diğer kutsal metinlerde de rastlamak mümkündür. Tevrat'ın Yaratılış babının ilk âyetlerine göre Rab, başlangıçta göğü ve yeri yaratmış, yerin boş ve engin karanlıklarla kaplı olması üzerine "ışık olsun!" diye emretmiş ve ışık var olmuştur. Tanrı, sırasıyla suların arasını ayırmak için bir kubbenin var olmasını, göğün altındaki suların bir yere toplanıp karaların ortaya çıkmasını, yeryüzünün bitki, tohum ve meyve veren ağaçlar üretmesini, çeşitli canlıların ve insanın var olmasını emretmiştir. Kısacası Tevrat'a göre Rab yer ve gökteki her şeyi sözel emriyle (liyekün) altı günde yaratmış, yedinci günde ise istirahate çekilmiştir. ${ }^{2}$ Burada sözü geçen "istirahat" kelimesini İslâm inancı açısından değerlendiren bazı Selef âlimleri, bu ifadeyi Allah'ın emrini bitirmesi ve işlerini tamamlaması olarak açıklamışlardır. ${ }^{3}$

Zebûr'da Allah'ın her şeyi sözel emriyle yarattığını anlatan bölüm şöyledir: “Bütün yeryüzü Rab'den korksun. Bütün dünyada oturanlar O'ndan yılsın. Çünkü O söyledi ve oldu, 0 emretti ve sabit durdu." ${ }^{4}$ Ayrıca Rab meleklerin, güneşin, ayın, yıldızların ve göklerin üstündeki suların kendisine hamd etmesini istemektedir. Çünkü Rab emretmiş, bu emri üzerine varlıklar yaratılmış ve Rab onların aşamayacakları belli kanunlar var etmiştir. Buna göre ateş, kar, ağaçlar, hayvanlar ve insanlar olmak üzere yeryüzünde var olan her şey Rabb'in ismine hamd etmelidir. ${ }^{5}$ Eski Ahit'te Tanrı'nın doğaya yansıyan ve insanlık tarihine yön veren bu yaratıcı sözü (davar), Helenistik kültürde "logos" kavramı ile ilişkilendirilmiş, onun dünya hayatını devam ettiren ve evrenin ruhu olduğuna inanılan bir ilke olduğu kabul edilmiştir. 6 Yuhanna İncili'nde de başlangıçta Tanrı ile birlikte var olan ilk şeyin O'nun sözü olduğu, her şeyin bu söz aracıllı̆ıyla yaratıldı ̆̆ı, var olan hiçbir şeyin sözsüz

1 İskender Pala, “Kün”, Türkiye Diyanet Vakfı İslâm Ansiklopedisi (Ankara: TDV Yayınları, 2002), 26/552. Belagatçllara göre hitabın emir, nehiy, haber ve istihbar olmak üzere dört șekli vardır. "Kün feyekûn" ifadesi tekvinî bir emirdir. Abdülkāhir Bağdâdî, Usûlü'd-dîn, thk. Ahmed Şemseddin (Beyrut: Dâru'l-Kütübü'l-İlmiyye, 2001), 238.

2 Kitab-ı Mukaddes (İstanbul: Kitabı Mukaddes Şirketi, 2003), Yar. 1:1-18.

3 Ebû Muhammed Abdullah b. Müslim İbn Kuteybe, el-Maârif, thk. Servet Ukkâşe (Kâhire: Dâru'lMaarif, ty.), 9-11. Kendisinin Selefin yolunu izlediğini belirten İbn Teymiyye, peygamberlerin haber verdiği gibi Allah'ın yeri ve göğü altı günde yarattığını belirtir ve bu konuda Yâsîn Sûresi 82. ayeti delil getirerek O'nun ezelde iradesiyle mütekellim olduğunu söyler. bk. Takiyyüddîn Ahmed İbn Teymiyye, Mecmû'u fetâvâ: Kitâbü'l-Kur'ân, thk. Âmir Cezzâr - Enver Baz (b.y., t.y.), $12 / 103$.

Mez. 33: 8-9.

Mez. 148: 1-13.

Michael Ebstein, Mysticism and Philosophy in al-Andalus: Ibn Masarra, Ibn al-Arabi and the Ismaili Tradition (Leiden: E.J. Brill, 2013), 33-34. 
olamayacağı bilgisi yer alır.7 Hıristiyanlar Allah'ın bu sözünün Hz. Meryem'e bırakılan Hz. Îsâ olduğuna inanmışlar, onu Allah'ın zâtından kaynaklanan ezelî sözü ve kelimesi olarak kabul etmişlerdir. ${ }^{8}$ Böylece Hıristiyanlıkta Hz. Îsâ, ezelî ve ebedî logosun cisimleşmiş, ete kemiğe bürünmüş hali olarak karşımıza çıkmaktadır.

Semavî dinlerde ve kültürlerde yer alan yaratıcı söz anlayışının Arapça karşılığı “kelime" dir ve bu kavram Kur'an'da kün, emir, kelâm, ruh (ruhu'l-emîn) ve irade ile bağlantılı olarak ilahî kararların formüle edildiği ve iletildiği söz anlamına gelmektedir. ${ }^{9}$ Kur'an-ı Kerîm'de “ol” anlamına gelen "kün” (كن) emri sekiz yerde zikredilir. ${ }^{10} \mathrm{Bu}$ âyetlerde Allah Teâlâ, bir şeyin olmasını istediğinde sadece "ol" (kün) demesinin yeterli olduğunu, o şeyin de hemen oluverdiğini (feyekûn) ve bu sözünün gerçek olduğunu bildirmektedir.11 Âyetlerdeki kün lafzı "istediğimiz zaman, hükmettiğimiz zaman" cümlesinde olduğu gibi, çoğu zaman Allah'ın iradesi ile ilişkilendirilmektedir. Yüce yaratıcı Âl-i İmrân Sûresi 59. âyette ise kendi katında Hz. Îsâ'nın durumunun Hz. Âdem gibi olduğunu, onun önce topraktan sonra da kün emriyle yaratıldığını bildirmektedir. Bu âyet diğerlerinden farklı olarak şart edatı içermemekte ve geçmiş zaman siygasıyla Allah'ın Hz. Âdem'i topraktan yarattığını, sonra bizzat "ol" sözünü söylediğini, onun da var olduğunu haber vermektedir. Önceki âyetlerde yoktan yaratmaya işaret edilirken burada insanın topraktan ve babasız yaratılması söz konusudur. Bu sebeple canlılık kazandırmayı ve insan sureti vermeyi ifade eden "kün" emri, insanın maddî varlığının topraktan çıkarılmasının ardından zikredilmiştir. ${ }^{12}$

Müslümanlar içerisinde kün kavramına ayrı bir önem vererek onu yaratma teorisinin temeline yerleștiren Bâtınî-İ́smâilîler, bu kelimeyi oluşturan kâf (ك̧) ve nûn (ن) harflerinin gerçek birer cisimsel surete sahip olduğunu iddia etmişlerdir. İsmâiliyye'nin itikadî ve fikrî görüşlerini sistemleştiren Ebû Hâtim er-Râzî (öl. 322/933), Yeni Eflâtunculuğun da etkisinde kalarak Mutlak Bir olan Allah'ın "kün" emriyle, bütün varlıkların kaynağını oluşturan ilk aklı yarattığını, ondan da ruhî ve maddî âlemlerin ortaya çıktığını savunmuştur. Dolayısıyla daha sonra İhvân-ı Safâ risâlelerine de etki ettiği görülen bu anlayışta Tanrı ile akıl arasında yer alan kün emri, ilk aklın sebebidir ve akıl da Tanrı'nın kelimesiyle yaratılan ilk ruhanî varlıktır. ${ }^{13}$ Ayrıca Râzî̀ye göre kâf ve nûn harfi Allah'ın yaratmasının illeti olan kelime için "beden”, hareket ve sükûn ise "ruh" konumundadır. Ebû Hâtim'in bu görüşüne karşı

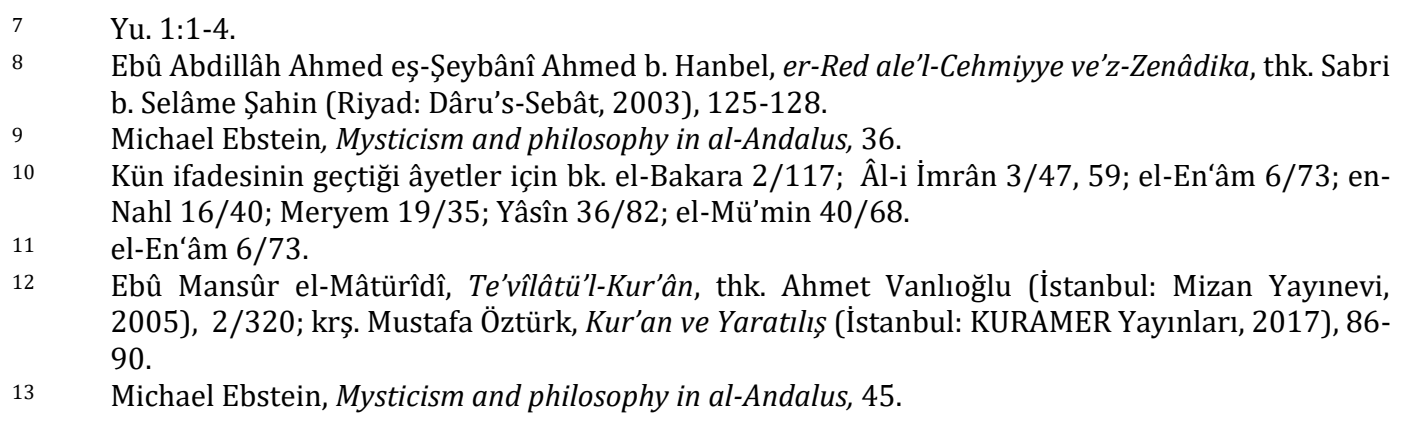

13 Michael Ebstein, Mysticism and philosophy in al-Andalus, 45. 
çıkan Ebû Ya'kûb es-Sicistânîye (öl. 393/1003) göre kelâmın hazineleri harflerdir ve peygamberler de bu harfleri kullanarak kutsal kitapları oluşturmuşlardır. 0 , bu harflerin Kûnî-Kader (كوني قدر) terkibinde toplanan yedi ulvî harf olduğunu, yaratmanın bu harflerle gerçekleştiğini ve her bir devir sahibinin bu yedi harfe sahip olduğunu iddia etmiştir. ${ }^{14}$ Kün ile emir arasında bağlantı kuran ve Hz. Ali'yi kelâm ile özdeşleştiren bazı İsmâilîler de Hz. Ali'nin varlıklardaki yaşam kaynağı olduğunu ve varlıklara hulûl ettiğini söyleyerek kâf ve nûn harfine sembolik anlamı aşan gerçeklik boyutunda bir değer yüklemişlerdir. Bu teoride Hz. Ali'nin kelâm olmasının yanı sıra, Fâtımî halifesi Müstansır-Billâh'ın (öl. 487/1094) kâf ve nûn sahibi oluşu gibi uzak yorumlara da yer verilmektedir. ${ }^{15}$

Kün emri tasavvuf literatürüne dâhil olduktan sonra, Şiî-Bâtınîlerde olduğu gibi bir takım gnostik şekiller kazanarak özellikle vahdet-i vücutçu düşüncenin bir parçası haline gelmiş, bazı sûfilerce de "kün" emrinde yer alan harflerin rakamlara denk geldiği ve bu rakamların belli anlamlara sahip olduğu iddia edilmiştir. ${ }^{16}$ İbn Meserre (öl. 319/931)17 ve İbnü'l-Arabî̀ye (öl. 638/1240) göre konum olarak Tanrı'dan aşağıda ve ilk aklın üstünde yer alan kün emri, her şeyin yaratılmasının illetidir ve yaratılan her şey kün emrinin bir tecellisidir. "Kün" emrine küllî iradenin sûreti ve yaratma vasıtası olduğu için “kelimetü'l-hazret" ismini veren İbnü'l-Arabî, ikinci mertebede ilahî ilimde sabitlik kazanmış mümkinlerin hakikatlerinin (a'yân-ı sâbite) "kün" emriyle șehâdet âleminde hâricî vücûdlar ile taayyün ettiğini belirtmektedir. ${ }^{18}$ Ona göre "ol" emri Allah'ın konuşmasıdır ve harfler nasıl insanın

14 Ali Avcu, Horasan-Maveraünnehir'de İsmailîlik (İstanbul: Marmara Akademi Yayınları, 2018), 217-218; krș. Michael Ebstein, Mysticism and philosophy in al-Andalus, 41-43.

15 Yunus Öztürk, "Hanefî-Mâtürîdî Geleneğin Mutasavvıf Bir Müellifi Ve Mesnevî Türü Eseri Olarak Âșık Pașa Ve Garibnâme Üzerine Karșllaștırmalı Bir Analiz", Sünni-İrfani Geleneğin 14. Yüzyıl Temsilcisi Âşık Paşa ve Türkçe Mesnevisi Garibnâme Üzerine İncelemeler, ed. Yunus Öztürk (İstanbul: Ensar Neşriyat, 2020), 160-161.

16 İbnü'l-Arabî, İsevî ilmin, harflerin ilmi olduğunu söyler. Bu nedenle Hz. Îsâ'ya üfleme verilmiștir. Hz. Îsâ kabirdeki surete ya da topraktan yaptı̆̆ kuş suretine üflemiş, bu üfleme ile ilahî izin doğrultusunda suret canlanmıștır. Dolayısıyla "ol" kelimesinin hakikatini bilen kimse İsevî ilmi öğrenmiş demektir. Üfleme hayatın ruhu olan yüreğin içinden çıkan havadır. Hava çıkış yolu kesintiye uğradığında harfler ortaya çıkar, bunlar birleştiğinde ise manalarda duyusal hayat ortaya çıkar. Bu ilahî mertebeden âleme gözüken ilk șeydir. Buna göre bileșik olarak meydana gelmiş ilk kelime kün sözüdür ve üç harften (كون) oluşur. Bu üç harfin her biri de üç harften oluşur ve böylece kökü üç olan dokuz sayısı meydana gelir. Basit sayılar dokuzun varlığıyla kün kelimesinden meydana gelir. İbnü'l-Arabî̀ye göre bu dokuz veya kün, dokuz felektir. Dokuz feleğin toplamının hareketi ve gezegenlerin dolaşımıyla dünya ve içindeki șeyler meydana geldiği gibi yine onların hareketleriyle de yok olacaklardır. bk. Muhyiddîn İbnü'l-Arabî, Fütûhât-ı Mekkiyye, çev. Ekrem Demirli (İstanbul: Litera Yayıncılık, 2007), 2/31-35. Bazı risâlelerde ise kün emrinin âmir ile bir olduğu ve âlemin altı günde yaratılmasını sembolize eden altı harften meydana geldiği yorumu yapılır. bk. Nokta Sembolizmi: Noktatü'l-Beyân Risâlesi, nşr. Mehmet Tabakoğlu - Şükrü Maden (İstanbul: İnsan Yayınları, 2020), 97.

17 Empedokles'in felsefesinden etkilenen İbn Meserre, Kurtuba'da doğmuş, tasavvufî eğilimleri ve kelâmî görüşleriyle meșhur olmuştur. 0 , âlemin ezelî olduğunu, Allah'ın âleme müdahalesinin şanına yakışmayacağını, bu sebeple âlemin arş tarafından yönetildiğini savunmuştur. Mustafa Çağrıcı, "İbn Meserre", Türkiye Diyanet Vakfi İslâm Ansiklopedisi (İstanbul: TDV Yayınları, 1999), 20/188-193.

18 Mahmut Erol Kılıç, “İbnü'l-Arabî, Tasavvuf”, Türkiye Diyanet Vakfi İslâm Ansiklopedisi (İstanbul: TDV Yayınları, 1999), 20/503; Mustafa Sinanoğlu, "Logos", Türkiye Diyanet Vakfi İslâm 
nefesinde görünür hale gelirse, varlıklar da "kün" emriyle Rahman'ın nefesinde görünür hale gelmektedir. ${ }^{19}$

Bu tür bâtınî ve işarî yorumların İslâm dünyasında yayılması üzerine "kün" emrinin mecazî mi yoksa hakiki mi olduğu problemi, yaratma sıfatı açısından da kelâm bilginlerinin gündemini meşgul etmiştir. Nitekim Allah'ın her şeyi yoktan yarattığına inanmakla birlikte bu yaratmanın nasıl ve ne zaman gerçekleştiği sorusu, kelâm âlimleri açısından ayrı bir önem arz eder. Kelâm ilminde "kün" emrinin mahiyeti konusu, kaynağını "tekvin" tartışmasından alır. Dolayısıyla kün emri, tekvin ve fiilî sıfatlar tartışması bağlamında Eş'arîlerle Mâtürîdîlerin ihtilaf ettiği konular içerisinde zikredilir ve her iki gelenek açısından yaratma doktrini çerçevesinde tekvin konusunu mukayeseli olarak ele alan çalışmalar bulunmaktadır. ${ }^{20}$ Ancak her ne kadar iki mezhep arasındaki ihtilaflı noktalardan biri olarak kaydedilse de kün emrinin mahiyetine Eşarâler gibi yaklaşan Mâtürîdî bilginler olduğu gibi Mâtürîdîler gibi yaklaşan Eş'arî bilginler de bulunmaktadır. Bu mezhep içi görüş farklarının yanı sıra kün emri ile kudret, kelâm ve tekvin sıfatı arasında kurulan ilişki, Eş'ariyye ve Mâtürîdiyye arasındaki ihtilafları konu alan eserlerde yeterli biçimde ele alınıp tartışılmış değildir. İlgili tartışmalara bir katkı sağlayacağını düşündüğümüz bu makale, Kur'an'da yaratmaya delalet eden "kün" emrinin kelâmcılar tarafından hangi açılardan tartışıldığını ortaya koymayı ve Eş'arîler ile Mâtürîdîlerin konu hakkındaki görüşlerini mukayeseli bir biçimde incelemeyi hedeflemektedir. Bu bağlamda öncelikle Ehl-i hadis âlimleri ile Mu'tezile ve Küllâbiyye gibi diğer mezheplerin konuya bakışı ele alınacak, ardından Eş‘ariyye ve Mâtürîdiyye kelâmcılarının "kün" emri etrafındaki ihtilaflarına yer verilecektir.

\section{1. İlk Dönem Ehl-i Hadis Bilginleri ve Kelâmcllara Göre Kün}

Emevî döneminin sonlarına doğru kün lafzıyla ilgili tartışmalar daha çok Cehmiyye ile Ehl-i hadis âlimleri arasında Allah'ın kelâmının ezelîliği ekseninde ortaya çıkmıştır. Bu konunun yaratma bağlamına kayarak Eş'arîyye ile Mâtürîdiyye arasında ihtilaflı bir hale dönüşmesi ise ilahî fiillerin tekvin merkezli olarak ele alınmaya başlanmasıyla ilgilidir. İlk dönem kaynaklarında Ehl-i hadis âlimleri, Allah'ın kelâmının yaratılmış olduğunu ve O'nun Hz. Mûsâ ile doğrudan konuşmadığını iddia eden Cehmiyye'yi, "kün” emrinin zikredildiği âyetleri gerekçe göstererek reddetmişlerdir. Bu bağlamda Hasan-ı Basrî (öl. 110/728), nesnelerin

Ansiklopedisi (Ankara: TDV Yayınları, 2002), 25/213; Michael Ebstein, Mysticism and philosophy in al-Andalus, 51-54.

19 Ayrıntılı bilgi için bk. Emrah Kaya, "Sonsuz Tecellî ve Daimî Yaratma: İbn 'Arabî ve İbn Teymiyye'nin Yaratma Meselesine Ezelî Fiil Olarak Bakıșı", Ankara Üniversitesi İlahiyat Fakültesi Dergisi 57/2 (2016), 84; Michael Ebstein, Mysticism and philosophy in al-Andalus, 53-56.

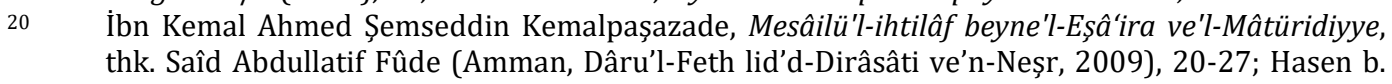
Abdilmuhsin Ebû Azbe, Ravzatu'l-behiyye fî mâ beyne'l-Eşâira ve'l-Mâtüridiyye (Haydarabad: Dâiretü'l-Maârifi'n-Nizâmiyye, 1322), 39-43; Abdürrahim b. Ali Şeyhzâde, Nazmu'l-ferâid ve cem'u'l-fevâid (Mısır: Matbaatü'l-Edebiyye, 1317), 17-20; İbn Kemal Ahmed Şemseddin Kemalpaşazade, Mesâilü'l-ihtilâf beyne'l-Eşấira ve'l-Mâtürîdiyye, thk. Saîd Abdullatif Fûde (Amman, Dâru'l-Feth lid'd-Dirâsâti ve'n-Neşr, 2009), 20-27. 
Allah'ın "ol” emriyle var olduğunu savunurken²1 Ahmed b. Hanbel (öl. 241/855), Hıristiyanların ve Cehmiyyenin Hz. Îsâ'nın durumu hakkında yanıldıklarını söyleyerek Nahl Sûresi'nin 40. âyetiyle delil getirmektedir. Hıristiyanlar, Hz. Îsâ'nın Allah'ın zatından kaynaklanan ezelî sözü ve kelimesi olduğunu kabul ederken Cehmiyye ise hem kelimetullah olan Îsâ'nın hem de ilahî kelimelerin mahlûk olduğunu ve Îsâ'nın Allah'ın yaratılmış bir sözü olduğunu söylemiştir. İki görüşü de hatalı bulan Ahmed b. Hanbel'e göre Hz. Îsâ, Allah'ın Hz. Meryem'e kün emriyle ulaştırdığı bir sözüdür. Hz. Îsâ "kün" sözüyle var olmakla birlikte bu sözün kendisi de değildir. Çünkü kün Allah'ın sözüdür ve yaratılmış olamaz. Böylece Hz. Îsâ'nın "kelimetullah" olmasının Allah'ın kün emri neticesinde gerçekleştiğini açıklayan Ahmed b. Hanbel, Allah'ın yeri ve göğü yaratmadan önce ezelî kün sözünü söylediğini, bunları kün emriyle yarattığını ifade eder.22

Ebû Ubeyd el-Kāsım b. Sellâm'dan (öl. 224/838) “Allah'ın kün sözünün yaratmanın başlangıcının sözü olduğu ve yaratma ile sözün ayrı olduğu” görüşünü nakleden İmam Buhârî (öl. 256/870), Hz. Îsâ'nın ve Hz. Âdem'in "ol” sözüyle yaratıldığını, bütün mahlûkatın Allah'ın emrine tabi olduğunu belirtir. 0, “Gök ve yerin O'nun emriyle durması O'nun âyetlerindendir."23 âyetini delil getirerek Allah'ın burada yaratma kelimesini kullanmadığını, bu sebeple her şeyin "ol” emriyle yaratıldığını savunmaktadır. Ayrıca onun naklettiğine göre İbn Abbâs'a "Kader nedir?" diye sorulmuş, o da "Yaratma ve emir O'na mahsustur."24 âyetiyle cevap vermiştir. 25

İbn Kuteybe (öl. 276/889), Tevrat'a göre yer ve göğün yaratılmasından sonra her şeyin kün emriyle yaratıldığını ifade eder ve hadis âlimlerinden yaptığı nakillerle ruh, nur ve zulmet gibi pek çok şeyin tek tek "kün" emriyle yaratıldığını belirtir. ${ }^{26}$ Dârimî ise Kur'an'ın yaratılmış olduğunu iddia eden Cehmiyye’yi Allah'ı konuşmaya güç yetirememekle itham etmeleri ve O’nun kün sözünü lafzî olarak söylemediğini savunmaları nedeniyle eleştirmektedir. Onun nezdinde bu görüş, Allah’ı konuşmaya güç yetiremeyen putlarla aynı konuma indirgemekten başka bir şey değildir. ${ }^{27}$ Böylece Ehl-i hadis âlimlerinin kün âyetlerini te'vil etmeden ve zahirî anlamından uzaklaştırmadan her şeyin ezelî bir "kün" sözüyle yaratıldığını kabul ettikleri anlaşılmaktadır.

"Kün” emrini Ehl-i hadis'ten farklı yorumlayan Abdullah b. Küllâb (öl. 240/854), tekvin-mükevven birlikteliğini savunduğu için fiilî sıfatların yaratılmış olduğunu belirtmiştir. Bu görüşün bir yansıması olarak Allah'ın "kün” demeden hiçbir şeyi yaratmadığını kabul etmiş, ancak "kün” emrinin halk (yaratma) değil, ezelî kelâm

\footnotetext{
21 Ebû Mansûr el-Mâtürîdî, Te'vîlâtü'l-Kurân, thk. Ertuğrul Boynukalın (İstanbul: Mizan Yayınevi, 2006), 5/385.

Ahmed b. Hanbel, er-Red ale'l-Cehmiyye ve'z-Zenâdika, 125-128.

er-Rûm $30 / 52$.

el-Arâf 7/54.

Muhammed b. İsmail el-Buhârî, Halku ef'âli'l-'ibâd: İlahî Kelâmın Müdafaası, çev. Yusuf Özbek (İstanbul: İz Yayıncılık, 2019), 40-41.

İbn Kuteybe, el-Maârif, 9-15.

Ebû Saîd ed-Dârimî, er-Red ale'l-Cehmiyye (Kuveyt: Dârü's-Selefiyye, 1985), 173-174.
} 
olduğunu, Allah'ın her şeyi "ol” sözü ile yarattığını ve kelâmın ezelî olduğunu vurgulamıștır. ${ }^{28}$ İbn Küllâb’ın bu yorumunun kendisinden sonra Ebü'l-Hasan el-Eş'arî (öl. 324/935) ve mezhebi tarafından da takip edildiği görülecektir.

Mu'tezile bilginleri ise kelâmın ezelî olduğu takdirde Allah'ın ezelde emreden, nehyeden ve haber veren olacağını, oysa ortada muhatap yokken ma'dûma emir ve nehiyde bulunmanın sefeh olduğunu savunmaktadır. ${ }^{29}$ Ayrıca harfler çeşitli seslerden ibarettir. Ses ise devamlılığı düşünülemeyen bir arazdır. Bu sebeple kelâm ezelî bir sıfat değil, Allah'ın konuşmak istediğinde bir mekânda yarattığı fiilidir. Dolayısıyla kâf ve nûn harfinden oluşan "kün" emri de gerçekte söylenmiş sözel bir ifade olamaz. Aksine kün sözü, Allah'ın yaratmasının kolaylığını gösteren temsilî ve mecazî bir anlatımıdır. ${ }^{30}$ Fahreddîn er-Râzî’nin bildirdiğine göre ma'dûmu "şey" olarak kabul eden bazı Mu'tezile âlimleri de yokluğun var olmadan önce zatlar, a'yanlar ve hakikatler şeklinde mümkün olduğunu, Allah'ın ma'dûma zatlar kılmak (ceale) şeklinde değil de bu zatları var (mevcûd) kılmak şeklinde etki ettiğini savunmuştur. ${ }^{31}$ Buna göre Allah, bir şeyi yaratmak istediği zaman nesnenin sabit olan hakikatine varlık kazandırmakta, dolayısıyla "kün" emri mutlak anlamda yokluğa yöneltilmemektedir. ${ }^{32}$

Kün lafzını ezelî kabul edenleri Mücbire olmakla eleştiren Kādî Abdülcebbâr, (öl. 415/1025) “Bir şeyi istediğinde, O'nun buyruğu 'ol!' demekten ibarettir; o da hemen oluverir." 33 âyetindeki kün emrinin kâf ve nûn harfinden meydana geldiğini hatırlatır. Burada ezelî olan kâf ve nûn olamaz, çünkü bunlar harftir. Kâf harfi nûn harfinden önce gelmekte, nûn söylendiğinde kâf ortadan kalkmaktadır. Şayet ezelî olan zatla kaim bir mana ise, âyette bu manaya delalet eden bir şey yoktur. "Ol” emrinin hiçbir şeyin oluşuna etki edemeyeceğini belirten Kādî Abdülcebbâr, izâ ('اذ) edatının mazi bir fiilin önüne geldiğinde (izâ erâde) gelecek ifade ettiğini, dolayısıyla âyetin Allah'ın gelecekte irade edip gelecek için söz söylediğine delalet ettiğini belirtmektedir.

Kādî Abdülcebbâr'a göre yaratılışla ilgili âyetlerin hakikî manada anlaşılması için bir delil ya da maslahatın olması gerekirken bu tür âyetlerde ne maslahattan ne de delâletten söz etmek mümkündür. Dolayısıyla burada sözün hakikatten mecaza

28 Ebü'l-Hasan Alî b. İsmâîl b. Ebî Bişr el-Eş'arî, Makālâtü'l-İslâmiyyîn ve ihtilâfü'l-musallîn: İlk Dönem İslam Mezhepleri, çev. Mehmet Dalkılıç - Ömer Aydın (İstanbul: Kabalcı Yayınevi, 2005), 359.

Ebu's-Senâ el-Lâmişî, Kitâbü't-Temhid li-kavâ'idi't-tevhîd, thk. Abdülmecid Türkî (Beyrut: Dârü'lGarbi'l-İslâmî, 1995), 72. Ebü'l-Hasen Kādı'l-kudât Kādî Abdülcebbâr, el-Muğnî fí ebvâbi't-tevhîd ve'l-adl: Halku'l-Kurân, thk. Taha Huseyn - İbrahim el- Ebyârî (Kahire: b.y., 1960), 7/3; Seyyid Şerif Cürcânî, Şerhu'lMevâkıf, çev. Ömer Türker (İstanbul: Türkiye Yazma Eserler Kurumu Başkanlığı, 2015), 3/156. Fahreddîn er-Râzî bu görüșü savunan grubun içerisinde Ebû Yâkub eș-Șahhâm, Ebû Ali el-Cübbâi, Ebu Hâş̧im el-Cübbâi, Ebü'l-Hüseyin el-Hayyât, Ebû Abdullah el-Basrî, Ebû İshâk b. Ayyâş ve Kâdî Abdülcebbâr'ın ismini zikretmektedir. Ayrıntılı bilgi için bk. Ebû Abdillâh Fahrüddîn Muhammed Fahreddîn er-Râzî, Muhassalu efkâri'l-mütekaddimîn ve'l-müteahhirîn mine'l-ulemâ, thk. Tâhâ Abdurraûf Sa'd (Kahire: Mektebetü'l-Külliyati'l-Ezheriyye, ts.), 59. Ömer Ali Yıldırım, "İslam Düşüncesindeki Yoktan Yaratma ve Kıdem Tartışmaları: Kelâmcılar ve İbn Sîna Merkezli Bir İnceleme”, Kelam Araștırmaları Dergisi [Kader] 10/2 (2012), 257-258. Yâsîn 36/82. 
aktarılması ve te'vil edilmesi zorunludur. Kün-feyekûn ifadesi ona göre Allah'ın bir şeyi yaratmasındaki kolaylığı anlatmak için kullanılan bir övgü ifadesidir. 0 şöyle der: "Bu ve aynı anlama gelen âyetlerden kastedilen, tereddüt etmeksizin eşyanın O'na süratle cevap vermesidir." 34 Bu Kur'an'daki şu âyete benzemektedir: "O göklere ve yere ikiniz de isteyerek ve istemeden gelin buyurdu. 'ísteyerek geldik' dediler." 35 Kelâmı bir fiil olarak değerlendirdiği için kün emrinin de ilahî kelâmı değil, fiili ifade ettiğini belirten Kādî Abdülcebbâr, bir insanın bir işi yapmak istediğinde onu doğrudan yapması gibi Allah'ın da bir fiili var etmek istediğinde kün emrini söylemesine gerek olmadığı kanaatindedir. Fiilin var edilmesinde geçerli olan onun yapılmasıdır. Nitekim şâhitte insan emirle fiil yapabilir, Allah'ın ise bir işe söz söyleyerek başlaması acziyeti gerektirir. ${ }^{36}$

Zemahşerî (öl. 538/1144) de kün emrinin Allah'ın yaratmak istediği zaman bu işin O'na çok kolay geldiğini ifade etmek için söylenmiş mecazî ve temsilî bir ifade olduğu görüşünü teyit eder. Nitekim diğer cisimler güçlerinin yettiği bir şeyi yaptıklarında doğrudan kudretin mahalliyle temas eder, belli aletler kullanır ve neticede meşakkat, yorgunluk ve zorluk ortaya çıkar. Allah ise bir şeyi yapmayı dilediğinde bu O'nun için en basit ve en hızlı (yapılabilecek) bir şey olmuş olur. Zemahşerî konunun daha iyi anlaşılması için şöyle bir örnek verir: Allah'ın takdir edip olmasını istediği işler, hiç imtinâ etmeksizin ve beklemeksizin hemen olmaya ve varlık kisvesine bürünmeye başlar. Bu tıpkı kendisine bir şey emredilen itaatkâr bir memurun, hiç beklemeden, imtinâ etmeden ve isteksizlik göstermeden emredilen şeyi derhal yapmaya başlaması gibidir. Bu denli yüce bir kudrete sahip olan zâtın durumu, diğer cisimlerin hallerinden tamamen ayrı olacaktır. Mümkün olan herhangi bir şeyi var etmek Allah için işte bu derece kolaydır. ${ }^{37}$

Hz. Îsâ'nın "ol" sözüyle yaratılmasını da aynı bağlamda değerlendiren Zemahşerî, Allah'ın çocuk sahibi olduğuna dair iddiaları "kün” emriyle reddederek Hıristiyanları yalanladığını ve susturduğunu söyler. Allah bu lafızla hangi cinsten olursa olsun istediği her şeyi bir "ol" sözü ile vücuda getiren zâtın, evlat doğuran canlılara benzemekten münezzeh olduğunu ifade etmek istemiş, dolayısıyla Hıristiyanların iddiasının imkânsız olduğunu açıklamıştır. ${ }^{38}$

Mu'tezile içerisinde Allah'ın bir şeyi yaratmayı irade ettiği zaman onu doğrudan "kün" sözüyle yarattığı görüşü ise Ebü'l-Hüzeyl el-Allâf'a (öl. 235/849) aittir. 0, bir mahalle ihtiyaç duyup duymaması açısından Allah'ın kelâmını ikiye

34 Ebü'l-Hasen Kādı'l-kudât Kādî Abdülcebbâr, Șerhu'l-Usûli'l-hamse: Mu'tezile'nin Beş Illkesi (Mu'tezile'nin Beş Esasının Açılımı), çev. İlyas Çelebi (İstanbul: Türkiye Yazma Eserler Kurumu Başkanlığı, 2013), 2/417-419; a.mlf., el-Muğnî, 7/168.

35 Fussilet 41/11.

36 Kādî Abdülcebbâr, Muğnî, 7/166-167.

37 Ebü'l-Kāsım ez-Zemahşerî, el-Keşşâf'an hakāikı ğavâmid't-tenzîl ve 'uyûni'l-ekāvîl fî vucûhi'-Te'vîl: Keşşâf Tefsiri, çev. Muhammed Coşkun vd. (İstanbul: Türkiye Yazma Eserler Kurumu Başkanlığı, 2016), 1/117-118; 3/966; 5/674-675; 5/1072. 
ayırmaktadır.39 Buna göre Allah'ın "kün" sözü hariç emir, nehiy ve haber gibi bütün sözlerinin bir mahalli bulunmaktadır. "Ol" emrinin ise yaratılmış olmakla birlikte herhangi bir mahalli yoktur. ${ }^{40}$ Allâf a göre bir șeyi yaratmak Allah'ın onu yok iken var etmesidir. Bu da onu irade etmesi ve kün (ol) demesiyle gerçekleşir. Allah'ın irade etmediği ve kün demediği bir şeyi yaratması caiz değildir. 0 böylece tekvinî emir (kün) ile teklifî emir arasını ayırarak yaratmanın mekânda olmayan yaratılmış bir irade ve söz olduğunu savunmaktadır. Yine o, bu bağlamda bekâyı Allah'ın bir şeye "bâki ol", fenâyı da "fâni ol" sözünü söylemesi olarak değerlendirmiştir. ${ }^{41}$ Allâf a göre Allah'ın bir şeyi yaratma ve yok etmedeki yolu hep “kün”le gerçekleşmektedir. Diğer taraftan onun bu görüşünün Mücbire'nin söyleminden farklı olduğunu savunan Kādî Abdülcebbâr, Mücbire'nin kün emrini ezelî kabul ettiğini, Allâf'ın ise Allah'ın hâdis bir fiili irade ettiğinde onu "ol" emriyle yaptığı görüşünü savunduğunu belirtir. Ancak bu O'nun yaratmaya sadece bu yolla kādir olduğu anlamına da gelmemektedir. Bu tıpkı "Beni ziyaret eden kimseye hediyem bir dirhemdir." sözüne benzer. Bu sözden maksat her ziyarete gelene para verileceği değil, hediye verildiğinde ne kadar verileceğidir. ${ }^{42}$ O halde kün emri de bir yaratmadır, ancak yaratmanın tek türü değildir. Ebü'l-Hüzeyl el-Allâf'ın tekvinin mükevvenden başka olduğunu söyleyerek diğer Mu'tezilîlerden ayrılması da bu görüşüyle paraleldir.43 Mu'tezile'den Abbâd b. Süleyman ise Allâf'ın söylediği gibi bir şeyin yaratılmasının "söz" olduğunu kabul etmiş, ancak ondan farklı olarak Allah'ın bu sözünün "kün” olmadığını zikretmiştir.44

Kerrrâmiyye mezhebine göre de yaratma Ebü'l-Hüzeyl'in savunduğu gibi Allah'ın iradesi ve "ol" kelimesiyle gerçekleşir. Fakat “ol” ifadesi Allah'ın dışında mahalsiz bir şey olarak değil, aksine Allah'ın zâtında hâdis olarak yaratılmıştır. Kerrâmîler yine ondan farklı olarak yaratmanın bekâyı da içerdiğine inanarak Allah'ın cismi veya arazı yarattığı zaman onun devamının ona "yok ol" deyinceye kadar zorunlu olarak onu takip edeceğini ileri sürmektedir. Dolayısıyla yaratılmış bir ibkâ (devam et) kelimesine ihtiyaç yoktur. "Ol” emrinin var etme ve yok etme şeklinde iki

39 Fahreddin er-Râzî, Ebü'l-Hüzeyl el-Allâf’n “Kün sözü Allah'ın melekler için yaptığı bir alamettir. Melekler bu sözü duydukları zaman bir işin ve bir şeyin meydana geleceğini anlarlar." görüşüne sahip olduğunu söylemektedir. Ebû Abdillâh Fahrüddîn Muhammed Fahreddin er-Râzî, Tefsîr-i Kebîr: Mefâtihu'l-gayb, çev. Lütfullah Cebeci vd. (İstanbul: Huzur Yayınevi, 1988), 3/398. Abdulkāhir Bağdâdî’ye göre Allâf, bu görüșüyle Allah'ın bir șeye "ol” demesini insanın "ol" demesi cinsinden kabul etmiş, aynı cinsten olan iki arazın arasında, bunlardan birinin bir mahalle ihtiyaç duyduğu, ötekinin ise bir mahalle ihtiyaç duymadı̆̆ı gibi bir ayrımda bulunmuştur. Ehl-i sünnet âlimleri "Allah'ın bir șey için "ol" sözü, bir yerde olmayan yaratılmıș bir arazdır." șeklindeki bu görüşünden dolayı Allâf'ı küfürle suçlamaktadır. Abdulkāhir el-Bağdâdî, el-Fark beyne'l-firak: Mezhepler Arasındaki Farklar, çev. Ethem Ruhi Fığlalı (Ankara: Türkiye Diyanet Vakfı, 1991), 92, 258-259.

41 Eş'arî, Makālât, 276-278, 358-359; Abdülkerîm eş-Şehristânî, Milel ve Nihal: Dinler, Mezhepler ve Felsefi Sistemler Tarihi, çev. Mustafa Öz (İstanbul: Litera Yayıncılık, 2008), 58.

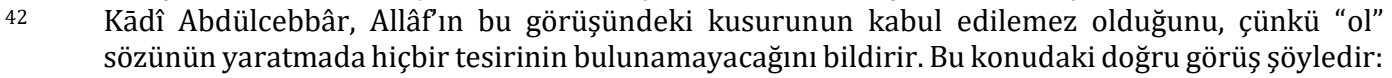
Allah Teâlâ yarattığı șeyleri kādir olarak yaratmaktadır. Kādî Abdülcebbâr, Şerhu'l-Usûli'l-hamse, $2 / 421$.

43 Ebü'l-Yüsr el-Pezdevî, Ehl-i Sünnet Akâidi, çev. Şerafeddin Gölcük (İstanbul: Kayıhan Yayınları, 1994), 100; Lâmișî, Kitâbü't-Temhid li-kavā'idi't-tevhîd, 76. Eş'arî, Makālât, 277. 
yönü olduğunu kabul eden bazı Kerrâmîler, her yaratma ve yok etme için ayrı kün sözünün söylendiğini savunurken bazıları da aynı cinsten olan nesnelerin tek bir yaratma ile var olduğunu, farklı nesneler için farklı yaratmaların bulunduğunu iddia etmişlerdir. ${ }^{45}$

\section{Eş’arî ve Mâtürîdî Mezhebinde Yaratma}

Kün ifadesi Eşáâi ve Mâtürîdî kelâmcıları arasındaki ihtilaflı meselelerden biridir. Onların bu konudaki görüş farklılığı, yaratma yani tekvin-mükevven hakkındaki ihtilaftan kaynaklanmaktadır. Tekvin sıfatını mahiyet açısından ilim, irade ve kudret gibi sübûtî sıfatlardan farklı görmeyen Mâtürîdîler, yaratmanın tekvin sıfatıyla gerçekleștiğini, fiilî sıfatların kaynağı olan tekvinin, bu sıfatın taalluku olan mükevvenden başka bir şey olduğunu savunmuşlardır. Buna göre tekvin, âlemin ve onun her bir parçasının var oluş vaktinde yaratılmasıdır. ${ }^{46}$ Tekvin mükevvinin fiili, mükevven ise tekvinin eseridir. Bu sebeple tekvin mükevvenden başkadır. ${ }^{47}$ Kudret ve irade eşyanın yaratılmasına doğrudan etki etmediği için yaratmada başka bir sıfata ihtiyaç vardır. Bu tesir tekvin sıfatıyla gerçekleşir.48 Ebû Hanîfe (öl. 150/767) fiilî sıfatların içerisinde tekvin kavramına yer vermemiş olsa bile risâlesinde bu sıfatı zikretmiş,49 İmam Mâtürîdî’den (öl. 333/944) itibaren de tekvin sıfatı yaratmanın merkezinde yer almıştır. Eş'arîlerin yaratmanın rolünü kudret sıfatına yüklemelerine karşı çıkan Mâtürîdî âlimleri, kudretin eserinin oluş (kevn) değil imkân olduğunu, kevnin ancak tekvinin eseri olduğunu belirtmişlerdir. ${ }^{50}$

Tekvin sıfatını sübûtî sıfatlar içerisinde zikreden Mâtürîdî, tekvinle diğer sübûtî sıfatlar arasında bir fark görmez. Sübûtî sıfatlar ezelî oldukları halde taallukları nasıl yaratılmışsa tekvin sıfatı da ezelî, ancak bu sıfatla yaratılan mükevven hâdistir. 0, tekvin sıfatının bu yönünü açıklamak üzere insanların kendi zamanlarında, kendilerinden önce gönderilen ilahî emir ve yasaklara, va'd ve va'îd konularına muhatap olmasını örnek gösterir. Nitekim insanlar geçmişte peygambere indirilen vahiyle gelen ilahî emir ve yasaklara, içinde bulunduğumuz şu anda da muhataptırlar. $\mathrm{Bu}$ gerçek karşısında kişi, ezeldeki tekvin sayesinde kendi zamanında yaratıldığını inkâr edemez. ${ }^{51}$

Șehristânî, Milel ve Nihal, 104.

Ebü'l-Muîn en-Nesefî, Kitâbü't-Temhîd li kavâidi't-tevhîd, çev. Hülya Alper (İstanbul: İz Yayıncılık, 2017), 51.

Ebû Şekûr es-Sâlimî, et-Temhîd fi beyâni't-tevhîd, thk. Ömür Türkmen (İstanbul: İSAM Yayınları; Beyrut: Dâru İbn Hazm, 2017), 136.

Beyâzîzâde Ahmed Efendi, İşâratü'l-merâm min ibârati'l-imâm, thk. Ahmed Ferîd el-Mezîdî (Beyrut: Darü'l-Kütübi'l-İlmiyye, 2007), 183-184.

Ebû Hanîfe faziletli amellerin kulların fiilleri olduğu için Allah'ın tahliki ve tekvini ile meydana geldiğini söylemiștir. bk. Nu'man b. Sâbit Ebû Hanîfe, "Vasiyyetü'l-İmâm Ebî Hanîfe", İmam-ı Azam'ın Beş Eseri, çev. Mustafa Öz (İstanbul: MÜİFAV Yayınları, 1992), 88.

Ebü'l-Muîn en-Nesefî, Tebsıratü'l-edille, thk. Hüseyin Atay (Ankara: Diyanet İşleri Başkanlığı, 1993), 1/412-415; Cürcânî, Șerhu'l-Mevâkıf, 3/180.

Ebû Mansûr el-Mâtürîdî, Kitâbü't-Tevhîd Tercümesi, çev. Bekir Topaloğlu (Ankara: İSAM Yayınları, 2002), 64. 
Allah'ın sonradan meydana gelen hiçbir sıfatının olmadığını düşünen Mâtürîdî’ye göre bir sıfatla vasıflandırıldığında O’nun bu niteliğe ezelden beri sahip olduğunu söylemek gerekir. Diğer taraftan O'nun ilminin, kudretinin, iradesinin ve tekvininin konusunu teşkil eden hususlardan söz edilince bu sıfatların taalluklarının ezelî zannedilmemesi için bunların zamanlarının da zikredilmesi ve mükevvenin vakte bağlı olduğunun belirtilmesi, yani "vakti gelince" ifadesinin vurgulanması gerekir. 52

Eş'arîlere göre ise tekvin gerçek değil, izafîdir, yaratma tekvinle değil, kudretle gerçekleşmektedir. Kudret tek bir sıfat olmakla birlikte biri ezelî, diğeri yaratılmış olmak üzere iki taalluku vardır. ${ }^{53}$ Mâtürîdîlerin iddia ettiğinin aksine oluş (kevn) kudretin eseridir, kudretin eseri makdûrunun olabilirliğini (imkân) değil, oluş ve varlığını gerekli kılar. Ancak bu kudreti mümkünler içerisinde belirli bir şeye tahsis edicinin olması gerekir. Bu tahsis edici bir tarafa taalluk eden "irade"dir. Bu sebeple yaratmada, oluşun kendisine taalluk eden irade aracilığıyla onda müessir olan kudretten başka bir sıfata ihtiyaç duyulmamaktadır. Yani kudret varken tekvin sıfatına gerek yoktur.54 Oysa Mâtürîdîlere göre Allah'ın bir șeye kudretinin yetmesi her zaman o işi yapmasını gerekli kılmaz. Mesela Allah semada bin tane güneş ve ay yaratmaya kâdirken sadece bir tane yaratmıştır. Çünkü Allah'ın kudreti bunlara gücü yettiği halde yaratma sıfatı tesir etmediği için bu olasılıklar varlık sahasına çıkmamıştır. Dolayısıyla kudret sıfatının tesiri imkân iken tekvin sıfatının tesiri ise yaratmadır. ${ }^{55}$ Mâtürîdîlerin kudret sıfatının imkâna taalluk etiği görüşünü eleştiren Kādî Beyzâvî’ye göre imkân, eşyanın zatî bir niteliği olup, kudret sıfatının taalluku sayesinde elde ettiği bir vasıf değildir. Ona göre kudretin eşyaya belli bir zamanda (hâdis) taalluku tekvin olarak isimlendirilir. Dolayısıyla tekvin ezelî bir sıfat değil, ezelî sıfat olan kudretin hâdis taallukundan ibarettir. Bu nedenle Allah'ın "Bir şeyi dilediği zaman, O’nun emri o şeye ancak "ol!" demektir. O da hemen oluverir." âyeti murâdın hemen gerçekleşmesini, onun derhal varlık kazanmasını anlatmaktadır."56

Bağdâdî (öl. 429/1037), yaratmanın kudret sıfatıyla gerçekleştiği görüşünü Ehl-i sünnet'in prensiplerinden biri olarak zikretmektedir. ${ }^{57}$ Matürîdî bilginlerini yaratma (tahlik) sıfatını kudret sıfatından farklı gördükleri için eleştiren Fahreddîn

52 Mâtürîdî, Kitâbü't-Tevhîd Tercümesi, 61-62.

53 Eş'arîlere göre kudret sıfatının salûhî (ezelî) ve tenzîcî (hâdis) olmak üzere iki taalluku bulunmaktadır. Salûhî taalluk bir şeyi yapmayı ve yapmamayı mümkün kılarken tenzîcî taalluk ise vakti geldiğinde varlıklara yaratılmaları anında taalluk eder ve o șey yaratılır. Eş'arîlere göre Allah'ın fiilleri kudret ile makdurat arasındaki taallukun kendisidir. Tencîzî taallukun etkisi rızık olursa rızıklandırma (terzik), hayat verme olursa ihya olarak isimlendirilir. Kudret sıfatının salûhî taalluku ezelî iken tenzîcî taalluku ise fiili var ettiği için yaratılmıștır. Eş'arîlere göre tekvin, eserine bakılmaksızın tencîzî kudretin taallukunun kendisidir. Mâtürîdîlere göre ise mükevvenin kendisinden sadır olan ezelî bir sıfattır. Mâtürîdî âlimleri salûhî taalluku kabul ederken tenzîcî taalluk yerine ezelî tekvin sıfatını koyarlar. bk. Kemalpaşazade, Mesâilü'l-ihtilâf beyne'l-Eşấira ve'l-Mâtüridiyye, 23-24.

54 Cürcânî, Şerhu'l-Mevâkıf, 3/156, 180-182.

55 Şeyhzâde, Nazmu'l-ferâid ve cem'u'l-fevâid, 9.

56 Nâsırüddîn Ebû Saîd Kādî Beyzâvî, Tavâli'u'l-Envâr: Kelâm Metafiziği, çev. İlyas Çelebi - Mahmut Çınar (İstanbul: Türkiye Yazma Eserler Kurumu Başkanlığl, 2014), 199-201.

57 Bağdâdî, el-Fark beyne'l-firak, 92. 
er-Râzî (öl. 606/1210) ise kudret sıfatının, fiil ve terke elverişlilik yoluyla tesir eden bir sıfat olduğunu belirtir. Tekvin sıfatı da aynı şekilde fiil ve terke elverişlilik yoluyla tesir ederse o zaman yaratma, kudret sıfatının kendisidir. Eğer tekvin zorunlu olarak taalluk ediyor ve taalluk ettiği şey zorunlu olarak var oluyorsa, bu durumda da Allah kendi istediği zaman yaratan olmaz, yaratmaya mecbur bir varlık olur. ${ }^{58}$

Teftâzânîye (öl. 792/1390) göre de yaratma, rızık verme, öldürme, diriltme gibi fiillerin kaynağı kabul edilen tekvin, kaçınılmaz olarak taalluk ettiği şeylerin farklılığı bakımından tahlîk (yaratma), terzîk (rızıklandırma), ihyâ (hayat verme) ve imâte (öldürme) vb. şekillerde isimlendirilen bir sıfattır. Ancak ona göre tekvinin kudret ve iradeden ayrı müstakil bir sıfat olduğuna dair bir delil yoktur. Her ne kadar kudretin mükevvenin varlığına ve yokluğuna nispeti bir ve eşit ise de kudret sıfatına irade sıfatının eklenmesiyle iki yönden biri tahsis ve tercih konusu yapılmış olur. Mâtürîdîlerin icmâ yoluyla Allah'ın hâlık (yaratan) olduğunu kabul etmelerini ve tekvini diğer sıfatlar gibi ezelî saymalarını eleștiren Teftâzânî, "Bu, hakiki sıfatlar için söz konusudur. Hâlbuki var etme, (îcâd) müessirin esere taallukundan anlaşllan manadan başka bir şey değildir. Bu ise (ezelde değil) gelecekte söz konusudur." sözüyle tekvin sıfatının yaratmadaki rolünü inkâr etmektedir. 59

Neticede Mâtürîdîlere göre Allah ezelden beri yaratıcıdır. O tekvin sıfatıyla vakti geldiğinde eşyayı yaratır. Hâlbuki Eş'arîlere göre yaratma, kudret sıfatının iradeyle tahsisi sonucu gerçekleşir ve Allah yarattığı anda yaratıcı olur. Fakat bu Allah'ın onunla kaim olduğunu göstermez. Nitekim O'nun ma'bûd olması, kendinde kaim bir sıfattan dolayı değil başkasında bulunan bir manadan dolayıdır. ${ }^{60}$ Bu şekilde Eş'arî ve Mâtürîdîlerin yaratma hakkındaki görüşleri kün emrinin anlaşılmasına da yansımış, yaratmanın tekvin sıfatıyla gerçekleştiğini düşünenler "kün" sözünün mecazî olduğunu kabul ederken yaratmada tekvin sıfatını kabul etmeyenlerin çoğunluğu ise "kün" sözünün yaratmaya etki eden ezelî bir kelâm olduğunu savunmuşlardır.

\section{Mâtürîdî Mezhebinde Mecazî Bir Söylem Olarak Kün Emri}

Başta İmâm Mâtürîdî olmak üzere onun izinden giden öğrencilerinin çoğu, yaratmanın ezelî tekvin sıfatı ile ortaya çıktığını kabul etmelerinden dolayı yaratmanın kün emrinin taalluku ile gerçekleşmediğini, aksine bu sözün Allah'ın

58 Ebû Abdillâh Fahrüddîn Muhammed Fahreddin er-Râzî, Me'âlimü usûli'd-dîn: Kelâm İlminin Esasları, çev. Muhammet Altaytaş (İstanbul: Türkiye Yazma Eserler Kurumu Başkanlığı, 2016), 114.

59 Sa'deddîn et-Teftâzânî, Şerhu'l-Akāid: Kelâm İlmi ve İslâm Akâidi, çev. Süleyman Uludağ (İstanbul: Dergâh Yayınları, 1999), 176; a.mlf., el-Makāsıdu'l-kelâm fî̀ 'akāidi'l-İslâm: Kelâm İlminin Maksatları, çev. İrfan Eyibil (İstanbul: Türkiye Yazma Eserler Kurumu Başkanlığı, 2019), 554556.

60 Sâlimî, et-Temhîd fi beyâni't-tevhîd, 123-124; Pezdevî, Ehli Sünnet Akaidi, 102, 106. Pezdevî Eş'arîlerin hiçbir zaman bu görüşünden dönmediklerini söyleyerek hayretini ortaya koymaktadır. Pezdevî, Ehli Sünnet Akaidi, 109. 
yaratmasının süratli ve kolay oluşundan kinaye olduğunu savunmuşlardır.61 Dolayısıyla kün ifadesi Allah'ın ezelde ma'dûma hitap ettiği bir kelâmı veya emri olamaz.

İmâm Mâtürîdî Te'vîlâtü'l-Kur'ân'da, kün emrinin geçtiği sekiz âyetin tefsirinde kün-feyekûn ibaresinden Allah'ın lafzî olarak kün dediğinin anlaşılmaması gerektiğini söyler. Nitekim Arap alfabesine ait kâf ve nûn harfinden oluşan kün, Allah'ın irade ve emrinin hızlı bir süre içinde meydana geldiğini haber veren ve anlaşılabilir manayı en kısa sözle anlatan bir ifade olup Arap dilinde anlaşılabilecek bir muhtevayı iki harfle ifade edecek "kün"den daha kısa bir söz bulunmamaktadır. 62 Yani kün kelimesi, Allah’ın işlerinin göz açıp kapamadan daha kısa bir sürede gerçekleştiğini haber vermektedir. Mâtürîdî’ye göre En'am Sûresi 73. âyette63 ifade edilen "kün" emri de insanları öldürdükten sonra yeniden diriltmenin Allah için bir zorluk ifade etmediğini ve bu olayın çok hızlı bir süratte meydana geldiğini belirtmek için kullanılmıştır. Burada tüm insanların yaratılması Allah için tek bir insanın yaratılması kadar kolaydır. ${ }^{64}$ Neticede sonsuza kadar vuku bulacak olan her şey Allah'ın "ol" emriyle vücut bulmuştur. Hem de ol kelimesinde kâf ve nûn harfleri veya başka bir şey söz konusu olmadan var olmuştur. Bu harfler Allah'ın irade ve emrinin ne kadar süratle yerine geldiğini veya bunun Allah için ne kadar basit olduğunu anlatmak için kullanılan bir mecazî söylemdir.65

Kitâbü't-Tevhîd'de ise tekvinin mahiyetinin beșer idraki tarafından kavranmasının mümkün olmadığını, bununla birlikte dile getirilebilecek en kolay anlatımın "ol" demekten ibaret olduğunu belirten Mâtürîdî, O’nun ilminde konumu belli olan her şeyin kün emriyle var olduğunu söyler. Bütün ilahî emir, nehiy, va'd ve va'îdler bu kün emrine dâhildir. 0 bu sözleriyle insanların kavrayış gücünün, failini meşgul edip yormayan bir tekvin fiilini anlamaktan aciz olduğunu, bu sebeple Allah'ın yaratma eylemini insanların zihinlerinde kün ifadesiyle anlaşılır kıldığını düşünmüş ve ilgili âyetlerin izahında te'vil yöntemini esas almıştır. 66

Ömer Nesefî (öl. 537/1142), Alâeddin es-Semerkandî (öl. 539/1144),67 Ebü’lBerekât en-Nesefî (öl. 710/1310) ve Şemseddin Konevî (öl. 788/1386) gibi bilginler kün emrinin Allah'ın yaratmasındaki kolaylı̆̆ı anlatan mecazî bir söz olduğu görüşünü savunan Mâtürîdî âlimlerindendir. Örneğin Ömer Nesefî, " $O$, göklerin ve yerin eșsiz-örneksiz yaratıcısıdır; bir șeyin olmasını dilediğinde ona 'ol!' der, o da hemen

Şeyhzâde, Nazmu'l-ferâid, 19; Tevfik Yücedoğru, Geçmişten Günümüze Doğru Ilim ve Din Açısından Yaratıllş̧ (Bursa: Emin Yayınları, 2006), 120.

62 bk. Ebû Mansûr el-Mâtürîdî, Te'vîlâtü'l-Kur'ân, thk. Ahmet Vanlıoğlu (İstanbul: Mizan Yayınevi, 2005), 1/220-221; 2/305-306, 319.

63 "O, gökleri ve yeri hak (ve hikmet) ile yaratandır. "Ol!" dediği gün her șey oluverir. O'nun sözü gerçektir. Sûra üflendiği gün de hükümranlı O'nundur. Gizliyi ve açığı bilendir ve O, hikmet sahibidir, her şeyden haberdardır."

64 Ebû Mansûr el-Mâtürîdî, Te'vîlâtü'l-Kur'ân, thk. Ertuğrul Boynukalın (İstanbul: Mizan Yayınevi, 2006), 5/105.

65 bk. Ebû Mansûr el-Mâtürîdî, Te'vîlâtü'l-Kur'ân, thk. Mustafa Yavuz (İstanbul: Mizan Yayınevi, 2008), 12/115.

66 Mâtürîdî, Kitâbü't-Tevhîd Tercümesi, 64.

67 Şeyhzâde, Nazmu'l-ferâid, 19. 
oluverir."68 şeklindeki âyetin tefsirinde, Allah'ın "ol" demesinden kastedilen şeyin sözel olarak hitap olmadığını belirtir. Çünkü "kün” emri, gerçek bir lafız olarak düşünülürse bu ma'dûm ya da mevcut bir şeye hitap etmek durumundadır. Var olmayan şeye hitap caiz değildir, çünkü ortada yoktur. Bu hitabın var olan bir şeye yönelmesi de mümkün değildir. Çünkü bu durumda o şey zaten vardır, kendisine "ol” demek mümkün değildir. Dolayısıyla bu ifade Allah’ın bir șeyin olmasını dilediği zaman onu var ettiği, onun da meydana geldiği anlamına gelmektedir. Bu âyetlerde istiare sanatının kullanıldığını belirten Nesefíye göre kün emri ile gerçek bir telaffuz değil, Allah'ın yaratma isteğinde hiçbir gecikmenin söz konusu olmadığı, bir fiilden dolayı Allah için herhangi bir yorulmanın söz konusu olamayacağı ve hükmünün nüfuzundan hiçbir mahlûkun dışarı çıkamayacağı kastedilmektedir. Nitekim Allah Teâlâ Al-i İmrân Sûresi'nin 47. âyetinde de "Bir ișe hükmedince ona sadece 'ol!' der; o da oluverir." sözüyle bir çocuğu babasız yaratmak istediğinde hiçbir gecikme söz konusu olmaksızın onu yaratacağını haber vermektedir. ${ }^{69}$

Şemseddin Konevî de Ehl-i sünnet inancına göre Allah'ın "ol” sözünün eşyanın varlığına taalluk etmediğini, kün emrinin Allah'ın yarattıkları üzerine olan kudretinin kemali sebebiyle mahlûkun süratle meydana gelmesinden ibaret olduğunu söyleyerek kün emrinin bu şekildeki te'vilinin Mâtürîdiyye mezhebinin genel kanaati olduğunu ifade etmiştir. ${ }^{70}$

“Kün” emrinin gerçek bir emir olmadığını belirten Ebü'l-Berekat en-Nesefî, ya ma'dûma ya da varlı̆̆a hitap edileceğini, kün emrinin ise her ikisine geçerli olamayacağını belirtir. 0 halde kün-feyekûn sözünden kastedilen tekvinin süratinden mecazdır. Bu ifade Allah'ın olmasını istediği şeylerin hiçbir engel ve duraksama olmaksızın meydana gelmesindeki hızı göstermektedir.71

"Kün âyeti, bir şeyi yaratmanın (tekvin) o şeyin kendisi olduğunu söyleyen kimseyi dolaylı bir şekilde reddetmektedir." diyen İmâm Mâtürîdî, kün âyetlerinin aynı zamanda tekvinin bu sıfatın taalluku olan mükevvenden farklı oluşuna delalet ettiğini söyler. Çünkü yaratma yaratılan nesneyle aynı olsaydı, bu âyetlerde Allah'ın önce tekvini ifade etmek için "ol" anlamında "kün", sonrasında mükevveni zikretmek için "olur" manasında "feyekûn" lafzını söylemesine gerek kalmazdı. Çünkü kün emri aynı anda tekvinin kendisi olur ve nesne var olurdu. 0 halde bu âyetler tekvinin mükevvenden başka olduğunun da açık bir delilidir. ${ }^{72}$

Mâtürîdî’nin izinden giden ve "ol" emriyle tekvin sıfatının ispatlanabileceği kanaatinde olan bazı Mâtürîdî bilginleri, Kur'an'da geçen "kün-feyekûn" ifadesini, Eş‘arîlerin tekvin-mükevven aynılığı ve yaratmanın hudûsu konusundaki görüşlerini nakzeden lügavî bir delil olarak ele almışlardır. Bu âlimler, Eş'arîlerin tekvinmükevven birlikteliğini kabul ettikleri halde kün emrinin ezelî, kün emriyle yaratılan

\footnotetext{
$68 \quad$ el-Bakara $2 / 117$.

69 Necmeddin Ömer en-Nesefî, et-Teysîr fi't-tefsîr: Ömer Nesefî Tefsiri, çev. Ali Benli (İstanbul, Türkiye Yazma Eserler Kurumu Başkanlı̆̆l, 2020), 2/70-71, 996.

70 Ali el-Kārî, Fıkh-ı Ekber Şerhi, çev. Hüseyin S. Erdoğan (İstanbul: Hisar Yayınevi, ty), 53.

71 Ebü'l-Berekāt en-Nesefî, Tefsîrü'n-Nesefî: Medâriku'l-tenzîl ve hakāiku't-te'vîl, thk. Yusuf Ali Bedevî (Beyrut: Dâru'l-Kelimeti't-Tayyib), 1998, 1/124.

72 bk. Mâtürîdî, Te'vîlâtü'l-Kur'ân, 1/220-221; 8/111-112.
} 
âlemin ise yaratılmış olduğu görüşünü eleştirmek ve onlara karşı istidlâlde bulunmak maksadıyla âlemin kün emriyle yaratılmasının, aslında tekvine delâlet ettiğini belirtmişlerdir.73 Nitekim "kün-feyekûn" ifadesi tekvin sıfatının aslı olan "kevn mastarından alınmıştır. Onlara göre kün lafzını "ezelî yaratıcı bir söz" olarak tasavvur eden Eş'arîlerin yaklaşımı, mantıksal açıdan pek çok çelişki ihtiva etmektedir. ${ }^{74}$

Kün sözünün yaratmanın süratini ifade ettiğini belirten Ebü'l-Muîn en-Nesefî, Eş'arîlerin kâinatın varlığını "kün" emrine bağlamalarının kendi sistemlerini çıkmaza sürüklediğini ifade eder. Nitekim kün-feyekûn ifadesinde kün tekvine, feyekûn ise mükevvene karşılık gelmektedir, bu da tekvin ve mükevvenin ayrı olduğunun önemli bir delilidir. Ona göre Eş'arîler'in söylediği gibi hem tekvinin mükevvenle aynı olduğunu hem de tekvinin kün emriyle meydana geldiğini, kün emrinin tekvin ve mükevvenden farklı, Allah'ın zatıyla kaim bir sıfat olduğunu söylemek çelişkili bir sözdür. Çünkü bu söz mükevvenden farklı olarak ezelî tekvinin varlığını ikrar etmeyi, ardından da bu sıfatın mükevvenin aynı olduğunu söylemeyi içerir. Benzer şekilde kâinatın oluşumunda bağlı bulunduğu "kün" emrinin ezelî oluşu, âlemin ezelî olmasını gerektirmediğine göre tekvinin kıdeminin mükevvenin kıdemini gerektireceğine hükmetmek bâtıl bir sözdür. Nesefî'ye göre Eş‘arîler, böylece tekvin sıfatını önce inkâr etmekte, ardından da kabul etmektedir. Ayrıca Eş'arîlerin Mu'tezile’ye karşı Allah'ın kelâmının ezeliyeti konusunda kün âyetini delil getirerek Allah'ın mahlûkatı kün ile yarattığını ispatladığını söyleyen Nesefî, aslında onların bu görüşüyle ezelî bir sıfat olan tekvinin varlığını ortaya koyduklarını savunur. ${ }^{75}$

Nureddîn es-Sâbûnî (öl. 580/1184) ve Ali el-Kārî de (öl. 1014/1605) Eş'arî'nin tekvin sıfatını yaratılmış kabul ederken âlemin kendisiyle yaratıldığı kün emrini ise ezelî kabul etmesinin kendi içinde farklı çelişkileri barındırdığını belirtmektedir. Nitekim âlem kün emriyle meydana geldiyse bu hitap aslında tekvindir ve mükevvenden başkadır. ${ }^{76}$

Nesefî ve Sâbûnî gibi “kün” ifadesinin kadîm olan tekvine, "feyekûn” ifadesinin ise mükevvene işaret ettiğini belirten Siğnâkî (öl. 714/1314), Eş'arîlerin kün emriyle

73 Osmanlı kelâm âlimlerinden Ramazan Efendi, "ol" emri ile ezelî olan tekvin sıfatının ispatlanacağı görüşüne karşı çıkmaktadır. Nitekim "feyekûn" ifadesi "ol" kelâmıyla mükevvenin ardarda olmasını gerektirir. Bu ikisinin birlikteliği ise ya ikisinin hâdis ya da ezelî olmasını zorunlu kılacaktır. O halde "ol” emri Allah'ın varlıklar üzerindeki kudretinin kemalini ve yaratmanın hızını anlatmak için zikredilen mecazî bir söylemdir. bk. Mustafa Aykaç, "Osmanlı Kelâmında Mâtürîdilik Vurgusu: Şerhu'l-Akâid Hâşiyelerindeki Tekvin Tartışmaları Bağlamında Bir İnceleme", KADER 18/1 (2020), 19-20.

74 Örnek için bk. Nûreddîn es-Sâbûnî, el-Bidâye fî usûli'd-dîn: Mâtürîdiyye Akaidi, çev. Bekir Topaloğlu (Ankara: Diyanet İșleri Başkanlı̆̆ı, 1995), 91; Ebû Azbe, Ravzatu'l-behiyye fî mâ beyne'lEşâira ve'l-Mâtüridiyye, 42-43; Mustafa Özgen, Eş'arî ve Mâtürîdî Mezhepleri Arasındaki Görüş Farklılıkları (Konya: Palet Yayınları, 2017), 236.

75 Ebü’l-Muîn en-Nesefî, Tebsıratü'l-edille, 1/412-415; a.mlf., Kitâbü't-Temhîd, 57; Hüsâmüddîn Hüseyn b. Alî b. Haccâc es-Siğnâkî, Kitâbü't-Tesdîd fî șerhi't-temhîd li'l-Siğnâkî, thk. Şemseddin Kerim (Almatı: Matbaatü Nur Mübarek, 2016), 192; krş. Temel Yeşilyurt, "Maturidilerde Tekvin Sifatı ve Temellendirilmesi", KÜIFD 1/1 (2017/1), 18-19.

76 Nureddîn es-Sâbunî, el-Kifâye fi'l-hidâye, thk. Muhammed Arûçi (İstanbul: İSAM Yayınları, 2014), 145-146; a.mlf., el-Bidâye fî usûli'd-dîn: Mâtüridiyye Akâidi, çev. Bekir Topaloğlu (Ankara: DİB Yayınları, 1995), 91; Ali el-Kārî, Fıkh-ı Ekber Şerhi, 63, 65. 
ilgili görüşlerinde çelişkiye düştüklerini ifade eder. İlk olarak Eşarîler kün hitabını Allah'ın zatıyla kaim ezelî bir söz kabul ederken, bu sözle âlemin yaratılmasını (tekvin) kastetmekte sonra da tekvinin hadis, mükevvenin ise aynısı olduğunu iddia etmektedirler. "Tekvin emri" ile "teklif emri" arasında fark olduğunu belirten Siğnâkî’ye göre Allah'ın âleme kün emriyle var olmayı emretmesi, emredilen ve vücup olmaksızın ezelde mevcut olan "icap emri"dir. Tekvin emri ezelde var olmayı gerektiren emir değildir. Aksine her mevcudun vaktinde var olmasını gerektiren bir emirdir. Teklif emri ezelde var olmayanlara bir sorumluluk yüklemez. Mükelleflere var oldukları ve büluğa erdikleri zaman yükümlülük yükler. Böylece "tekvin emri" Eş'arîlerde söze, Mâtürîdîlerde ise fiile karşıllk gelirken diğer taraftan Mâtürîdîler söz anlamını "teklif emri"ne vermektedir. İkinci çelişki ise onların "Allah'ın kün hitabındaki kelâmının ezelîliği, mükevvenin ezelîliğini gerektirmez” sözünü söyleyip ardından da tekvinin ezelî olduğunu söylemek mükevvenin ezelî olduğunu söylemeyi gerektirir, şeklindeki görüşü savunmalarıdır. Üçüncü çelişki ise şöyledir: Eş‘arîler "sıfatlar manalardan türeyen isimlerdir, bu mana kendisinde bulunan kimse bununla nitelendirilir" sözüyle Mâtürîdîlerle aynı düşünmektedir. Mesela sâkin kendisinde sükûn bulunan kimsenin ismidir. Hem Eş‘arîler hem de Mâtürîdîler Mu'tezile’ye karşı Allah'ı bir mahalde yarattığı kelâmla vasıflandırırken Eş'arîler, "Allah âlemi zatıyla kaim olmayan bir tekvinle yaratmıştır." sözüyle Mâtürîdîlerden ayrılıp Mu'tezile'nin yanında yer almışlardır.77

"Kün" lafzının, tekvinin süratinden mecaz olduğu görüşünü savunan Beyâzîzâde de bunu çoğu Mâtürîdîlerin kabul ettiğini, aynı zamanda kün ifadesinin Allah'ın eşyayı tekvinle yarattığına delalet ettiğini bildirmektedir. ${ }^{78}$

Mâtürîdî mezhebinin çoğunluğu bu şekilde "kün" emrinin mecazî bir ifade olduğunu kabul ederken, diğer taraftan Pezdevî (öl. 493/1100), Serahsî (öl. 483/1090) ve Ebû İshâk es-Saffâr (öl. 534/1139) gibi bilginler ise mezhebinin genel görüşünden ayrılarak kün emrinin tekvine değil, ezelî kelâma delâlet ettiğini savunmaktadır. Onlar yaratmanın tekvin sıfatıyla gerçekleştiğini kabul etmekle birlikte kün emrinin de yaratmada tesiri bulunan ezelî bir söz olduğunu, bu sebeple kün emrinin mecaz olarak anlaşlıp başka manalara te'vil edilemeyeceğini belirtmişlerdir. Kün ifadesi teşbih ve ta'tîl olmaksızın Allah'ın gerçek anlamda ezelî bir sözüdür. ${ }^{79}$

Ehl-i hadis'in kanaatini paylaşarak Mu'tezile'ye karşı kün âyetiyle Allah'ın kelâmının yaratılmış olamayacağını ispatlamaya çalışan Pezdevî, "Biz bir şeyi dilediğimiz zaman ona sözümüz sadece 'Ol' demektir, o da oluverir." âyetinin Allah'ın iradesi ve kün sözüyle eşyayı yarattığına delalet ettiğini söyler. Eğer Allah'ın kelâmı mahlûk olsaydı bunun da başka kelâmla, onun da başka bir kelâmla yaratılmış olması gerekirdi ve bu durum sonsuza kadar böyle devam ederdi. Bu ise Allah'ın hiçbir şey yaratmadığı anlamına gelirdi. Bu âyet Allah'ın sözlerinin ezelî olduğunu

Siğnâkî, et-Tesdîd șerḥu't-Temhîd fî kavấidi't-tevḥ̂id, 192.

Beyâzîzâde, İşâratü'l-merâm min ibârati'l-imâm, 183.

Ali el-Kārî, Fıkh-ı Ekber Şerhi, 112. 
göstermektedir. Pezdevî, kün sözünü tekvinin süratini ifade eden bir mecaz olduğunu düşünen ve eşyanın Allah'ın kelamıyla değil O'nun yaratmasıyla var olduğunu iddia eden Mu'tezile âlimlerinin görüşlerini eleştirir. Ona göre Allah'ın hem kün sözüyle hem de fiiliyle yaratması mümkündür. ${ }^{80}$ Sonuçta Pezdevî̀ye göre yaratma hem tekvin sıfatıyla hem de kün sözüyle yani kelâm sıfatıyla gerçekleşmektedir.

Serahsî, Mâtürîdîlerin savundukları kün emrinin mecazî olduğu görüşünü reddederek "Yine göğün ve yerin O'nun emriyle durması (kudretinin) alâmetlerindendir."81 âyetini delil getirmiş ve kün emrinin de gerçek anlamda bir kelâm olduğunu kabul etmiştir. Ona göre Allah'ın kelâmı bütün yaratılmış olanlardan önce söylenmiş ezelî bir sözdür. Allah mevcudatı üzerlerine hâdis olan bir şey geçmeden aletsiz ve hazırlıksız olarak yoktan var etmiştir. Bu husus Allah'ın varlıkları, kün emri ile yaratmasına engel değildir. ${ }^{82}$

Ebû İshâk es-Saffâr da öncelikle "kün" ifadesinin Allah hakkında eşyayı yaratmanın kolay olduğunu anlatmak için Arapçada söyleniş bakımından en kısa ve en basit kelime olduğu görüşünü dile getirir. Diğer taraftan o, tekvinin bu ilahî sözle gerçekleştiğini düşündürecek ifadelere yer verir. Saffâr, Allah Teâlâ'nın kün sözünü tek tek nesneleri yaratmadan önce söylemediğini, künün ezelde "Her bir şey vakti geldiğinde olsun." şeklinde tek bir kelâmla söylenmiş ezelî bir söz olduğunu belirtmektedir. Yani ona göre Allah, tek bir kelâmla "her şey vakti geldiğinde olsun" diyerek hitapta bulunmuştur ve bu söz kâf ve nûn harfinden oluşan lafzî bir kelâm değildir. Bu çerçevede Saffâr, seleften nakledilen "Allah ruh, nur ve zulmet için tek tek her birine kün deyip yaratmıştır.” yönündeki yorumu, hudûsu akla getirdiği için isabetli bulmadığını, usulcülerin savunduğu, "her şey vakti geldiğinde olsun" görüşünün daha isabetli olduğunu belirtir. Nitekim ma'dûma ve mevcuda hitap caiz değildir. Yine Allah'ın sözünün hâdis olması da mümkün değildir. 0 , isim vermeden bazı kimselerin kün âyetini sadece yaratma şeklinde te'vil ettiklerini söyleyerek eleștirir. Ancak kün âyetleri, yaratmanın sözle ilişkisini ortaya koyduğu için ona göre ilgili âyetleri te'vil etmek Kur'an'a muhalefet anlamına gelmektedir. ${ }^{83}$

Sonuç olarak eşyanın yaratılması Mâtürîdîlerin çoğunluğuna göre tekvin sıfatıyla, Pezdevî, Serahsî ve Saffâr gibi Hanefîlere göre ise hem tekvinle hem de ezelî kelâm olan kün hitabıyla gerçekleşmektedir. ${ }^{84}$

\section{Eş'arî Mezhebinde Ezelî Bir Kelâm (Söz) Olarak Kün Emri}

Kün emrini ezelî bir söz veya hitap kabul eden Eş'arîler bu sebeple konuyu Mâtürîdîlerin eserlerinde olduğu gibi tekvin meselesi altında değil, Allah'ın kelâmının veya emrinin ezelîliği başlığı içerisinde ele almayı tercih etmişlerdir. Yine onlar, ilahî

Pezdevî, Ehl-i Sünnet Akaidi, 84.

er-Rûm 30/25.

Ebû Bekr Şemsüleimme Serahsî, Usûlü’s-Serahsî, thk. Ebü'l-Vefâ el-Efgânî (Kahire: Dârü'l-Kitâbi'lArabi, 1954), 1/13, 18; krş. Ali el-Kārî, Fıkh-ı Ekber Şerhi, 112.

83 Ebû İshâk Saffâr, Telhîsü'l-edille li-kavâidi't-tevhîd, thk. Angelika Brodersen (Beyrut: el-Ma'hedü'lAlmani li'l-Ebhâsi'ş-Șarkiyye, 2011), 1/766-768.

84 Ali el-Kārî Pezdevî’nin savunduğu bu görüşün üçüncü bir görüş olduğunu söyler. Ali el-Kārî, FlkhI Ekber Şerhi, 54. 
kelâmı bir mahalde yaratılmış kabul eden Mu'tezile'ye karşı da kün emrinden hareketle cevap vermişlerdir. Başka bir deyişle kün emri bağlamında Eş'ariyye ile Mâtürîdiyye arasındaki tartışma tekvin-mükevven ayrılığı etrafında cereyan ederken aynı konu Eş'ariyye ile Mu'tezile arasında ise kelâm sıfatının ezelîliği problemine evrilmektedir. ${ }^{85}$

Yaratma (halk) ile kün emrini hakikatleri itibariyle iki ayrı şey olarak değerlendiren Ebü'l-Hasan el-Eş'arî, bu konuda "Yaratma (halk) ve emir O'na aittir."86 âyetine dayanır. Ona göre Allah Teâlâ bu âyette yaratma ve emir kavramlarını birbirinden kesin bir biçimde ayırmıştır. Yine burada zikredilen Allah'ın emrinin ve sözünün yaratılmış olmadı̆̆ı hususunda Müslümanların icmâsı bulunmaktadır. Aynı şekilde "Bir şeyi istediğinde, O'nun emri 'ol!' demekten ibarettir; o da hemen oluverir." 87 âyetinde geçen "izâ erâde" (istediğinde) ifadesi, yaratılmışların yok iken var olduklarına delalet eder. Kün emri de Allah'ın sözünün yaratılmamış olduğunu gösterir. Şayet Allah'ın "kün” sözü yaratılmış olsaydı, yaratma kün ile gerçekleştiğinden dolayı, Allah'ın onu da başka bir emirle yaratması gerekirdi. Bu durumda ya Dehrîlerin iddia ettiği gibi, her muhdes kün sözünün öncesinde başka bir muhdes sözün bulması gerekir, bu da sonsuza kadar sürüp giderdi ya da kün sözünün Allah'ın, kendisine emretmeksizin ("kün!" demeden) yarattığı bir sözü (kelâm) olması gerekirdi. Bu durumda da Allah'ın “kün feyekûn” beyanının anlamı kalmaz, Hz. Ali'nin getirdiği delil de bâtıl olurdu. Zira Hz. Ali, Hâricîlerin tahkim olayını reddetmeleri karşısında "Ben yaratılmış herhangi bir varlığı hakem kabul etmedim, Allah'ın kelâmını hakem kabul ettim.” sözünü söylemiş, bunun üzerine sahâbeden veya Hâricîlerden hiç kimse de bu söze karşı çıkmamıştır.88 Eş'arî, böylece ilahî kelâm olarak kün emrinin ezelîliğini vurgulamaktadır.

el-Lüma' adlı eserinde kün lafzına Kur'an'ın ezelîliği konusunda yer veren ve Allah’ın kelâmının ezelîliğini "kün” emriyle ispatlayan Eş'arî, Kur’an’ın yaratılmış olması durumunda, Allah'ın onu yaratırken kendisine kün (ol) demesinin gerekeceğini söyler. Hâlbuki Kur'an Allah'ın sözüdür ve bu sebeple O’nun sözünün kendisine hitap edilen nesne konumunda bulunması imkânsızdır. ${ }^{99} 0$, “Göğün ve yerin

85 Kemalpaşazade aslında Eş‘arî’ye nispet edilen âlemin kün hitabının taallukuyla yaratıldığı görüşünün doğru olmadığını söyler. Çünkü âlem kün sözünün değil, kudretinin taallukuyla yaratılmıştır. Ma'dûma tencîzî olarak emretmek imkânsız olduğu için âlemin kün hitabıyla var olması doğru değildir. Hitap kadîm, âlem ise hâdistir. Ona göre Eş'arî ve Mâtürîdî Allah’a kudret sıfatı nispet etmede birleştikleri için aralarındaki ihtilaf asli değildir. Kemalpaşazade, Mesâilü'lihtilâf beyne'l-Eşấira ve'l-Mâtüridiyye, 25. el-A'râf 54. İmâm Mâtürîdî’ye göre ise bu âyetteki "emir" kelimesi, eșyayı yaratmanın Allah'a ait olduğunu haber vermekte ya da O'nun mahlûkatı dilediği şekilde yaratmasına işaret etmektedir. bk. Mâtürîdî, Te'vîlâtü'l-Kur'ân, 5/105.

87 Yâsîn 36/82.

88 Ebü'l-Hasan Alî b. İsmâîl b. Ebî Bişr Eş'arî, Usûlü Ehli's-sünne ve'l-cemâa, thk. Muhammed Seyyid el-Celyend (Kahire: Mektebetü'l-Ezheriyye li't-Turâs, 2013),137-138; a.mlf., el-İbâne an Usûli'ddiyâne, thk. Abbâs Sabbağ (Beyrut: Dâru'n-Nefâis, 1994), 61-62.

89 Zira bu durum onun öncesinde bulunması gereken ikinci bir sözün varlığını zorunlu kılmaktadır. Geriye doğru gidildiğinde ise ikinci söz ve onun üçüncü sözle olan ilişkisi pek tabii ilk söz ve onun ikincisiyle ilişkisine benzeyecektir. Söz ile yaratma arasındaki bu münasebet, ardı ardına dizili sonsuz sayıda sözün varlı̆̆ını (teselsül) gerektirir ki, bu da aklen geçersiz bir husustur. Böyle bir 
Allah'ın emri ile düzen içinde durması da O'nun kanıtlarındandır."90 âyetinde zikredilen "emir" kelimesiyle yine O'nun kelâmının kastedildiğini, göğün ve yerin Allah'ın emri sebebiyle yere düşmeyip düzen içinde durduklarını belirtir.91 Bu sözüyle Eş'arî, evrenin ol emriyle yaratıldığı gibi evrendeki düzenin de ol emriyle devam ettiğini kabul eder görünmektedir. Eserlerinde "Allah bir sözü genel bir lafızla ifade etmişse, bu gerçekte o lafzın genel olduğunun kanıtıdır." şeklindeki ilkeyi sık sık tekrar eden Eş'arî, bir delile dayanmaksızın Allah'ın kelâmını hakiki anlamından çevirmenin yanlış olduğu kanaatindedir. Dolayısıyla Allah'ın "Halk O'nundur." sözüyle kastedilen mana bütün mahlûkatı yaratmasıdır. "Ve emir de O'nundur." ifadesinde ise yaratılmış olan her şeyin dişında başka bir şey zikredilmiştir.92 Yaratılmış tüm nesnelerin (halk) dışındaki bu ikinci șey ise ona göre kelâm veya sözdür. Bu da bize Allah'ın emrinin (söz) yaratılmamış olduğunu gösterir.93 İbn Fûrek de bazı Eş'arîlerin hocalarına "kün" sözünün yaratma (halk) olduğu görüşünü nispet ettiğini, oysa Eş‘arînnin bu görüşü hatalı gördüğünü söyler. Ona göre Eş'arî, bir șeyi yaratmanın yaratılan (halkın mahlûk), fiilin de meful olduğunu, sözün ise bunlardan başka bir şeyi ifade ettiğini söylemiştir.94 İbn Teymiyye ise Eş'arî'nin Seleften farklılaşarak İbn Küllâb’a tabi olduğunu, Allah'ın kelâmının kudreti ve meşieti ile gerçekleşmediğini düşündüğü için "kün feyekûn" ayetlerini te'vil ettiğini belirtir. ${ }^{95}$

Çoğunluk Eş'arî âlimleri bu konuda imamlarının yorumuna bağlı kalarak kün emrinin tekvine değil, ezelî kelâma delalet ettiğini, âlemin bu kün hitabiyla yoktan yaratıldığını ve Allah'ın yaratma hakkındaki sünnetinin bu emirle devam ettiğini belirtmişlerdir. ${ }^{96}$ Buna göre kudret sıfatının âlemin meydana gelmesine taalluku "ol" hitabıyla gerçekleşmektedir. Onlara göre şayet ezelî kün sözü yaratma olsaydı tekvinmükevven birlikteliğinden dolayı âlem de ezelî olacaktı. Dolayısıyla "kün" ifadesi tekvin değil, ezelî kelâmdır ve bu sözle yaratılan âlem ise hâdistir. Konu hakkında detaylı açıklamalarda bulunan Bâkıllânî'ye (öl. 403/1013) göre Nahl Sûresi'nin 40. âyeti Allah'ın kelâmının yaratılmamış olduğunun açık bir delilidir. Allah'ın kelâmı

ihtimal geçersiz olduğu takdirde Kuran'ın yaratılmışlı̆̆ı iddiası da geçerliliğini yitirir. Yine Allah'ın kendi sözünü yaratmak için ona hitapta bulunması mümkün olsaydı, benzer şekilde O'nun kendi iradesini de irade edebilmesi gerekirdi. Hâlbuki bu husus her iki tarafa göre de imkânsızdır. Bu yaklaşım yanlıș olduğuna göre Kur'an'ın yaratılmamışlığı da ortaya çıkmış olmaktadır. Ebü'l-Hasan Alî b. İsmâîl b. Ebî Bişr Eş'arî, el-Lüma' fi'r-red alâ ehli'z-zeyğ ve'l-bida': Eş'arî Kelâmı, çev. Kılıç Aslan Mavil - Hikmet Yağlı Mavil (İstanbul: İz Yayıncılık, 2016), 53-54. er-Rûm 30/25.

Eş'arî, el-İbâne an usûli'd-diyâne, 61-62.

bk. el-A'râf 54.

Eş'arî, el-íbâne an usûli'd-diyâne, 61-62.

İbn Fûrek, Mücerred, 66.

İbn Teymiyye'nin belirttiğine göre bu mesele Ehl-i hadis ile Küllâbiyye arasındaki ihtilaflı bir konudur. Ehl-i hadis'e göre Allah ezelden beri kudret ve meşietiyle konuşurken İbn Küllâb ve Eş'arî ise ihtiyari şeylerin hâdis olduğunu, Allah'ın hadis olan şeylerle kâim olamayacağı için O'nun kudret ve iradesiyle konuşmadığını savunmuşlardır. İbn Teymiyye, Mecmû'u fetâvâ: Kitâbü'l-Kur'ân, 12/54-55.

96 Sâbûnî, el-Bidâye fî usûli'd-dîn, 91; Ebü'l-Muîn en-Nesefî, Tebsıratü'l-edille, 1/449; Beyâzîzâde, İşâratü'l-merâm min ibârati'l-imâm, 184; Ebu'l-Muzaffer İsferâyînî, et-Tebsîr fi'd-dîn ve temyîzu'lfirkâti'n-nâciye ani'l-firaki'l-hâlikîn, thk. Kemal Yusuf el-Hût (Beyrut: Âlemü'l-Kütüb, 1983), 166; Yücedoğru, Geçmişten Günümüze Doğru İlim ve Din Açısından Yaratılış, 120. 
yaratılmış olsaydı yaratmada başka bir kün sözüne ihtiyaç duyulur, o da üçüncüye, üçüncü de dördüncü bir söze ihtiyaç duyardı ve bu sonsuza kadar sürüp giderdi. Böylece Allah'ın eşyayı yarattığı kün sözünün yaratılmış değil, kadîm olduğu anlaşılmış olur. ${ }^{97}$ Bâkıllânî, hocası gibi "Halk (Yaratma) ve emir O'na aittir." âyetini delil getirerek Allah'ın bu âyette yaratma ve emrin arasını ayırdığını, bu ikisinin başka şey olduğunu söyler. Şayet Kur'an mahlûk olsaydı, halk olurdu. Halk ile mahlûkun aynı olması halinde de bu âyetin "Yaratma ve yaratma O'na aittir." şeklinde bir tekrar ifade etmesi gerekirdi. Allah'ın faydasız söz söylemekten münezzeh olduğu ilkesinden hareket eden Bâkıllânî, emir kelimesinin ayrıca zikredilmesinden hareket ederek O'nun kelâmının emir, nehiy ve haber olması sebebiyle kün emrinin yaratılmış olamayacağını kaydeder. ${ }^{98}$ Böylece o da tıpkı hocası Eş'arî gibi kün âyetini te'vil etmek için hiçbir geçerli delilin bulunmadığını, bu sebeple konu ile alakalı âyetlerin zahiri üzere anlaşılması gerektiğini savunur. ${ }^{99}$

Bâkıllânî, kün sözünün ezelî kelâma delalet ettiği görüşünü dilcilerin kanaatleriyle de destekler. Arap dili uzmanları bir cümledeki fiilin mastarının ayrıca zikredilmesi durumunda bunun fiili onaylamak anlamına geldiği konusunda hemfikirdir. "En nekûle lehû kün feyekûn" âyetinde "kavluna" kelimesinin birinci mastar, "en nekûle" sözünün de ikinci mastar olduğunu belirten Bâkıllânî, bunun birinci mastarı tekit ettiğini söyler. Bu sebeple kün âyetinin zahirinden uzaklaştırılıp mecazî manada anlaşılamayacağını belirtir. Hatta ona göre Allah Teâlâ kün demeden hiçbir şeyi yaratmamıştır. Her şey başlangıçta olduğu gibi kün sözüyle yaratılmaya devam etmektedir. Kün sözü ezelî, bu sözle yaratılan âlem ise hâdistir.100

Bu konuda Bâkıllânî’nin görüşlerini takip eden Beyhakî (öl. 458/1066), Şehristânî (öl. 548/1153) ve Seyfeddin el-Âmidîye göre de (öl. 631/1233) “Yaratma ve emir O'na aittir." âyeti, ${ }^{101}$ yaratma ve emrin ayrı şeyler olduğunu ve eşyanın ezelî bir emir (söz) ile yaratıldığını göstermektedir.102 "Kün-feyekûn" ifadesinin tekvinî bir emir olduğunu vurgulayan Abdülkāhir Bağdâdî ise bazı Eş'arîlerin ma'dûma hitabı caiz görüp Allah'ın ezelde mükelleflere emreden ve nehyeden olmasını kabul ettiklerini, bazılarının ise Allah'ın ezelde ma‘dûma hitabını caiz görmediklerini, O’nun

97 Ebû Bekr Bâkıllânî, el-İnsâf fîmâ yecibu i'tikāduhu velâ yecûzü'l-cehl bihi, thk. Muhammed Zahid el-Kevserî (Kahire: Mektebetü'l-Ezheriyye li't-Türâs, 2000), 67.

98 Ebû Bekr Bâkıllânî, Temhîdü'l-evâil ve telhisü'd-delâil, thk. Mektebetü'l-İlmî (Beyrut: Müessesetü'l-Kütübi's-Sekafiyy), 2016. 271.

99 Aynı mantıkla Fussilet Sûresi 11. âyetteki sema ve arzın dile getirdiği "isteyerek geldik" cevabını da zahiri üzere anladığını belirten Bâkıllânî, insanların konuşma özelliğiyle diğer canlılardan ayrılmış olsa bile âyette haber verildiği gibi sema ve arzın da bir șekilde konușmasının mümkün olduğunu savunur. Nitekim Cenâb-ı Hakk’ın verdiği haber bu yöndedir. Bâkıllânî, Temhîd, 274275.

100 Bâkıllânî, Temhîd, 274-275.

101 el-A'râf 7/54.

102 Ebû Bekr Ahmed el-Beyhakî, "Kitâbü'l-İtikād ve'l-hidâye”, el-Mesâilüll-ihtilâf beyne'l-Eşaira ve'lMâtürîdiyye, mlf. Şemseddin İbn Kemal Paşa, thk. Saîd Abdullatif Fûde (Amman: Darü'l-Feth li'dDirasati ve'n-Neşr, 2009), 142-143; Abdülkerîm eș-Şehristânî, Nihâyetü'l-ikdâm, thk. Alfred Guillaume (London: Oxford University, 1934), 296; Seyfeddîn Âmidî, Gâyetü'l-merâm fî ilmi'lkelâm, thk. Hasan Mahmud Abdüllatif (Kahire: Vizaretü'l-Evkāf, 1971), 109-110. 
mahlûkatı yaratmadan önce emreden ve nehyeden olmakla vasıflandırılamayacağını söyleyerek bu konuda diğerlerinden ayrıldığını kaydeder. ${ }^{103}$

Görüldüğü üzere kün emri konusunda Eş'ariyye'nin çoğunluğu Ehl-i hadis çizgisine yakın durarak naslarda geçen temsilî ifadeleri zahiri üzere anlamış ve te'vilden uzak durmuşlardır. Bu konuda Gazzâlî̀nin (öl. 505/1111) Eş'arîler'in nazarî alanda birçok nassı te'vil ederken bazı hususlarda ise Hanbelîlere yakın durdukları ve nasların çoğunu olduğu gibi te'vilsiz kabul ettikleri yönündeki tespiti, ilk dönem Eş'arî âlimleri için haklı görünmektedir. ${ }^{104}$ Nitekim Allah'ın faydasız söz söylemekten münezzeh olacağı ilkesinden hareket eden çoğu Eş'arîler "Allah, Mûsâ ile bizzat konuştu."105 âyetini Hz. Mûsâ'nın Allah'ın nefsî kelâmını işittiği şeklinde zahiri anlamışlardır. ${ }^{106}$ İbn Küllâb, Eş'ariyye ve Ehl-i hadis ister sadece mana olsun isterse harflerden meydana gelsin Allah'ın kadîm kelâmını işittirmesi için insanlarda bir idrak yaratabileceği konusunda hemfikirdir.107 Yine onlar Kur'an'da zikredilen Allah'ın kendisinden başka ilah olmadığına şahitlik ettiğine yönelik haberini, ${ }^{108}$ lafzî bir şahitlik olarak anlamışlar ve Allah'a bu birliğini ezelde "tasdik eden" anlamında "mü'min" sıfatı nispet etmişlerdir.109

Neticede Allah'ın kelâmının ses ve harflerden oluşmadığını kabul eden Eş'arî âlimlerinin doğrudan kâf ve nûn harfini değil, ancak bizzat kün ibaresini nefsî kelâma delalet eden ezelî bir söz ve emir olarak algıladıkları anlaşılmaktadır. Bu sebeple Mâtürîdîlere göre kâf ve nûn harfinden oluşan kün lafzı, lafzî kelâma delâlet ederken Eş'arîlerde ise nefsî kelâma delâlet etmektedir. ${ }^{110}$ Nitekim Eş'arî ve takipçilerine göre Allah'ın kelâmı O'nun emridir. Aslında kelâm tek bir sıfattır, ancak taalluk ettiği şeyler emir, nehiy ve haber şeklinde kısımlara ayrılmaktadır. Eş'arî, "Allah'ın kelâmı ezelde emir, nehiy, haber ve istihbar olmaktan uzaktır." diyenleri hatalı görmüş, kelâmın

103 Abdülkāhir Bağdâdî, Usûlü'd-dîn, 127, 238.

104 Ebû Hâmid el-Gazzâlî, Faysalu't-tefrika beyne'l-İslâm ve'z-zenâdıka: İslam'da Müsmaha, çev. Süleyman Uludağ (İstanbul: Dergâh Yayınları, 2016), 39-40.

en-Nisâ 4/164.

Bâkıllânî, Temhîd, 274-275.

Ebû Bekr Ahmed el-Beyhakî, el-Esmâ ve'sıfat (Beyrut: Dâru'l-Kütübi'l-İlmiyye, 1998), 1/91.

"Allah, melekler ve adaleti yerine getiren ilim sahipleri O'ndan başka ilah olmadığına şahitlik etti ..." Âl-i İmrân 3/18.

109 bk. Hikmet Yağlı Mavil, "Ehl-i Sünnet Kelâmında Halku'l-Îmân Tartışması”, AİBÜ İlahiyat Fakültesi Dergisi 7/14 (2019), 443.

110 Cürcânî, Eş'arı̂’nin "Kelâm, nefsî anlamdır." dediğinde, ashabın bundan kastının sadece lafzın medlûlü olduğunu, ibarelerin de gerçek kelâma delalet etmeleri nedeniyle mecazen kelâm olarak adlandırıldığını zannettiklerini söyler. Hatta ashab, lafızların Eş'arî’ye göre yaratılmış olduğunu, ancak O'nun gerçek sözü olmadığını belirtmiştir. Oysa bu yoruma göre Allah'ın gerçek kelâmıyla meydan okuması söz konusu olmadığı gibi okunan ve ezberlenen de O'nun gerçek kelâmı değildir. Eş'arî’nin görüşünün yanlış anlaşıldığını belirten Cürcânî, aslında hocalarının nefsî kelâmı lafız ve anlamın her ikisini de kuşatan kelâm, yani Allah'ın zatıyla kaim, mushaflarda yazılı, dillerde okunan ve zihinlerde ezberlenen şey olarak kabul ettiğini söyler. 0 , bunun müteahhir âlimlerin görüşüne aykırı olmakla birlikte doğru olduğunu da ekler. Cürcânî, Şerhu'l-Mevâkıf, 3/164-166. Bir diğer Eş'arî bilgin Cüveynî de bazen nefsî kelâma ibarelerin, bazen de ortak olarak kullanılan işaret ve benzeri şeylerin delalet ettiğini, nefsî kelâmın bazı kelimeler, bir takım işaretler veya yazı adı verilen şekillerle de ifade edilmesinin mümkün olduğunu söylemektedir. İmâmu'lHaremeyn el-Cüveynî, Kitâbü'l-İrşâd: İnanç Esasları Kılavuzu, çev. Adnan Bülent Baloğlu vd. (Ankara: Türkiye Diyanet Vakfl, 2016), 100-102. 
şahitte ve gaipte bu sıfatlardan ayrılmasının akledilir olmadığını savunmuştur. Ona göre Allah'ın nefsî kelamı bu manaları barındırmaktadır. ${ }^{111}$ Eş'arî âlimleri de imamlarının kanaatini paylaşarak Allah'ın ezelî kelâmının emretme, nehyetme, haber verme, vad ve va'îdde bulunma özelliğini taşıdığını ve bunların tek bir kadîm kelâm olduğunu savunmaktadır. Kelâmın emir, yasak, soru, haber ve nidaya bölünmesi yalnızca taalluk bakımındandır. Bu durumda bir olan kelâm, bir şeye özel tarzda taalluku bakımından haber olurken başka bir şeye taalluku bakımından da emir olmaktadır.112 Böylece Eş'arîlerin nezdinde kün ifadesi iki harf olmanın ötesinde ezelde Allah'ın kelam sıfatının emir şeklindeki taalluku, yani tekvinin yokluğundan kaynaklanan açığı kapatan "kozmolojik bir emir" olarak karşımıza çıkmaktadır.

Diğer taraftan Eş'arîlerin tekvin sıfatını reddedip kün lafzını ezelî bir söz olarak kabul etmesi Mâtürîdîlerin de ifade ettiği gibi bazı çelişkileri gündeme getirmiştir. Örneğin tekvin sıfatını reddedip onun rolünü kudrete yükleyen Eş'arîler, "kudret sıfatı varken tekvine ihtiyaç yoktur" görüşüyle Mâtürîdîlere itiraz etmektedir. 0 zaman kudret varken "kün"e de ihtiyaç kalmamalıdır. Yine onlar, Mâtürîdîlerin tekvin görüşüne itiraz ederken, ezelde mevcut olan böyle bir yaratma sıfatının yaratılmışların da (mükevven) ezelî olmasını gerektireceğini ileri sürmüşlerdir. Öte yandan Eş'arîler kün emrinin, ezelde emredilen olmadığı halde ezelde mevcut olduğunu kabul etmektedir. Oysa tekvin sıfatı da aynı şekilde eşyanın ezelde var olmasına yönelik bir emir (hüküm) değil, aksine her bir varlığın kendi var oluş vaktinde var olmasına yönelik bir emirdir. O halde tekvinin âlemin ezelîliğini gerektireceğini söyleyip kün emrinin ise ezelîliği gerektirmeyeceğini söylemek Nesefî’nin daha önce dile getirdiği gibi açık bir çelişki arz etmektedir. ${ }^{113}$ Ayrıca Eş'arîlerin ma'dûmu yokluk halinde şey kabul ettikleri için Mu'tezile'yi eleștirirken diğer taraftan da Allah'ın "kün "emriyle yokluğa hitapta bulunduğunu savunmaları içine düştükleri başka bir çelişkidir.

Kâf ve nûn harfinden oluşan kün hitabının ezelî kabul edildiği takdirde ortaya çıkacak açmazları fark eden bazı Eş'arî âlimler, Mâtürîdîlerin konu hakkındaki yorumlarını benimseyerek mezhebinin genel kanaatinden ayrılmışlardır. Örneğin Gazzâlî, el-iktisâd adlı eserinde Mu'tezile'nin kün âyetlerinin manasını anlayamayacak derecede zayıf düşüncede olduklarını söyleyerek Allah'ın ezelde emredici ve nehyedici olduğunu, harflerin ise ezelî kelâma delalet eden bir delil oldukları için şeriatın onlara saygı gösterilmesini gerekli kıldığını hatırlatır. ${ }^{114} \mathrm{O}$ bu eserinde üstü kapalı konuşurken, diğer bazı eserlerinde ise daha açık bir ifadeyle "kün" emrinin kudretten kinaye olduğunu belirtmektedir. Çünkü bu âyet zahiri üzere anlaşılırsa o zaman "ol" hitabı bir şeyin meydana gelmesinden önce olduğu için ma'dûma hitap anlamına gelir ki, bu aklen imkânsızdır. "Ol” sözü bir şeyin varlığından sonra olursa,

\footnotetext{
111 İbn Fûrek, Mücerred, 66-67.

112 Ebû Abdillâh Fahrüddîn Muhammed Fahreddîn er-Râzî, el-Muhassal: Ana Meseleleriyle Kelam ve Felsefe, çev. Eşref Altaş (İstanbul: Klasik Yayınları, 2019), 162; Cürcânî, Şerhu'l-Mevâkıf, 3/160.

113 Ebü'l-Muîn en-Nesefî, Tebsiratü'l-edille, 1/449-451.

114 Gazzâlî, el-iktisâd fi'l-ítikād: İtikatta Orta Yol, çev. Ömer Dönmez (İstanbul: Hisar Yayınevi, ts.), 114-115; 140-143.
} 
bu durumda tekvinden müstağni olan şeye tekvin taalluk etmiş olur. Dolayısıyla burada kün âyetlerini zahiri üzere anlamamak için yeterli aklî delil mevcuttur. ${ }^{115}$ İhyấ'da ise sadece üç hadisi te'vil eden Ahmed b. Hanbel'in “kün-feyekûn” âyetini te'vil etmediğini ve ona tabi olanların "kün" lafzını Allah'ın harf ve sesten meydana gelen bir hitabı olarak düşündüklerini söyler. Yine "Bu Müslümanlar Allah'ın olacak her şeye daima "ol" diye hitap ettiğine ve onun da olduğuna inanmışlardır." diyen Gazzâlî, âyetin te'vil edilmesi gerektiğinden yana tavrını ortaya koyar.116

Gazzâlî̀nin kün âyetlerini te'vil etme yönünde başlattığı bu eğilim, müfessir Eş'arîler tarafından daha da ileri taşınmıştır. Örneğin Fahreddîn er-Râzî ve Kādî Beyzâvî (öl. 685/1286) açıkça kün emrinin ma'dûma söylenmiş ezelî bir söz oluşuna karşı çıkarak Mâtürîdî ile Mu'tezile âlimlerinin görüşünü benimsemişlerdir. $\mathrm{Bu}$ konuda Mu'tezile'nin Eş'arîlere karşı ileri sürdüğü itirazları aynen kabul eden Fahreddin er-Râzî, Eş'arî âlimlerinin Nahl Sûresi 40. âyeti delil getirerek Allah'ın bir şeyi yaratmak istediğinde "ol" dediğine ve o şeyin meydana geldiğine inandıklarını söyler. Nitekim Eşarî âlimlerine göre kün emri yaratılmış olsaydı ona da "kün" denmesi gerekir ve bu sonsuza kadar giderdi. Oysa bunun kuvvetli bir delil olmadığını söyleyen Râzî, tam tersine kün sözünün harf ve seslerden meydana geldiği için yaratılmış olduğu yönündeki delillerin daha kuvvetli olduğunu belirtir.117

Râzî’ye göre Allah'ın olmasını istediği şeye “ol” deyip, o anda o şeyin meydana gelmesinin mümkün olmadığını ispatlayan ilk delil "kün" sözünün kâf ve nûn harfinden oluşmasıdır. "Kün" hitabında kâf önce, nûn da sonra zikredilmektedir. Harfler ezelî olmadığı için kün emri de ezelî olamaz. Kün âyetindeki "izâ" edatı da geleceğe ait bir ifadedir. Feyekûn de bu edattan sonra geldiği için muhdesten sonra gelen de muhdes olur. Yine Arap diline göre feyekûn kelimesindeki fe harfi, takip fası olup bir önceki cümlede geçen "ol" emri ile ardından meydana gelen mükevven arasında zaman bakımından bir boşluğun bulunmadığını ifade eder. Bu durumda yaratılmış olan mükevvenin hemen öncesinde gerçekleşen kün emrinin de yaratılmış olması icap eder.118 Dolayısıyla Allah mahlûkata gerçekte "kün" sözünü söylemiş olsaydı ya onlar henüz var olmadan önce ya da varlık alanına girdikten sonra kün demesi gerekirdi. Varlıklar henüz yokken "ol” demek caiz değildir. Çünkü mevcut olmayana mevcut olmadığı zamanda hitap etmek akılsızcadır. Allah'ın mevcut olan varlığa mevcut olmalarını söylemesi de doğru değildir. Âl-i İmrân Sûresi 59. âyette ifade edildiği gibi Hz. Îsâ'nın durumunun Hz. Âdem'in durumu gibi olması, Hz. Âdem'in önce topraktan yaratılıp sonradan da ol sözünün söylenmesi, Razî̀ye göre bu görüşün doğruluğunu ispatlar. Çünkü bir şeyden sonra gelen, öncesinde müessir olamaz. Yani ol sözü, topraktan yaratıldıktan sonra zikredildiği için yaratmada etkili

115 Yücedoğru, Geçmişten Günümüze Doğru İlim ve Din Açısından Yaratılıș, 120-121; krş. Ebû Hâmid Gazzâlî, "el-Kânûn külli fi't-te'vîl: Gazzâlî’nin Te'vil Hakkında Basılmamış Bir Eseri”, çev. M. Şerefeddin, Darülfünun İlahiyat Fakültesi Mecmuası 4/16 (193), 55.

116 Gazzâlî, İhyâu ulûmi'd-dîn, çev. Ahmed Serdaroğlu (İstanbul: Bedir Yayınevi, 2002), 1/261 1/261.

117 Fahreddin er-Râzî, Mefâtihu'l-gayb: Tefsîr-i Kebîr, 14/220.

118 Ebû Abdillâh Fahrüddîn Muhammed Fahreddin er-Râzî, Halku'l-Kur'ân beyne'l-Mu'tezile ve Ehlü's-sünne, thk. Ahmed Hicâzî es-Sekkâ (Beyrut: Dârü'l-Cîl, 1992), 65. 
değildir. Râzî bütün bu delillerden sonra kün sözünün ezelî bir söz olmadığının açıklığa kavuştuğunu söyleyerek geriye kalan tek yöntemin te'vil olduğunu belirtir. Ona göre bu konudaki en güçlü te'vil ise Allah'ın kün demesindeki maksadı, eşyanın yaratılmasında ilahî kudretin süratle nüfuz etmesi ve Allah'ın eşyayı düşünmek, yardım almak ve denemeksizin yaratması olarak değerlendirilmektir. Râzî, kün âyetinin "Allah göğe ve arza 'ister isteyerek, ister istemeden gelin' dedi. Onlar da 'isteyerek geldik' dediler."119 şeklindeki âyete benzediğini söyler. Bu âyette yerin ve göğün konuşması değil, ilahî kudretin hiçbir engelle karşılaşmadan yer ile göğün yaratılmasına süratli bir șekilde taalluk etmesi söz konusudur. ${ }^{120}$ Oysa daha önce zikredildiği üzere Bâkıllânî bunu yer ve göklerin gerçek konuşması şeklinde anlamıştır. Râzî bu çerçevede "Yaratma da emir de O'na aittir."121 âyetindeki emir kelimesini diğer Eş'arîler gibi Allah'ın kelâmı olarak yorumlamamış, aksine İmâm Mâtürîdî gibi bu âyetin Allah'ın azamet ve kudretini beyan ettiğini söylemiştir. 0 , ashabının bu âyete dayanarak halk ve emrin arasını ayırdığını ve emri ezelî söz kabul ettiklerini söyleyerek onları açıkça eleştirir. Neticede ona göre kün-feyekûn ifadesi gerçek bir emir ve hitap değildir. ${ }^{122}$ Fahreddîn er-Râzî sadece bu görüşüyle değil, Allah'ın nefsî kelâmının işitilemeyeceği ve "Ezelde emir, nehiy değil sadece haber vardır." şeklindeki görüşleriyle de mezhebinin genel kanaatinden ayrılmaktadır.123

Kādî Beyzâvî de "kün feyekûn" ifadesinden gerçek bir emir ve emre itaatin anlaşılmaması gerektiğini belirtir. Bu ayetler Allah'ın iradesinin taalluk ettiği şeyin ara vermeksizin ve duraksamaksızın oluşmasına bir örnek teşkil etmektir. ${ }^{124}$ Künfeyekûn ifadesi, Allah'ın murat ettiği şeyleri duraksamadan, iş yapmaya gerek duymadan ve alet kullanmadan meydana getirme kudretini ifade etmektedir. ${ }^{125}$ Beyzâvî̀ye göre yaratma Allah'ın öncesinde yaptığı bir hazırlıkla değil sadece irade ve kudretle gerçekleşir. Bu sebeple nasıl eşyayı madde ve modele gereksinim duymaksızın yaratması mümkünse onu var olduktan sonra iade etmesi de mümkündür. ${ }^{126} \mathrm{~Hz}$. Meryem'e hitaptaki kün emri ise Allah'ın aşama aşama, sebeplerle yaratmaya kadir olduğu gibi tek bir seferde yaratmaya da kadir olduğunu göstermektedir. ${ }^{127}$ Beyzâvî böylelikle yaratmada irade ve kudretin yeterli olduğuna, dolayısıyla kün sözüne ihtiyaç bulunmadığına dikkat çekmektedir.

Netice itibariyle Gazzâlî, Fahreddîn er-Râzî ve Kâdî Beyzâvî gibi bazı müteahhir Eş'arî âlimleri, kün emrinin ezelî kelâma delaleti şeklinde anlaşılan ilk dönem mezhebin eğiliminden uzaklaşmışlar ve Mâtürîdîlerin kün emrinin

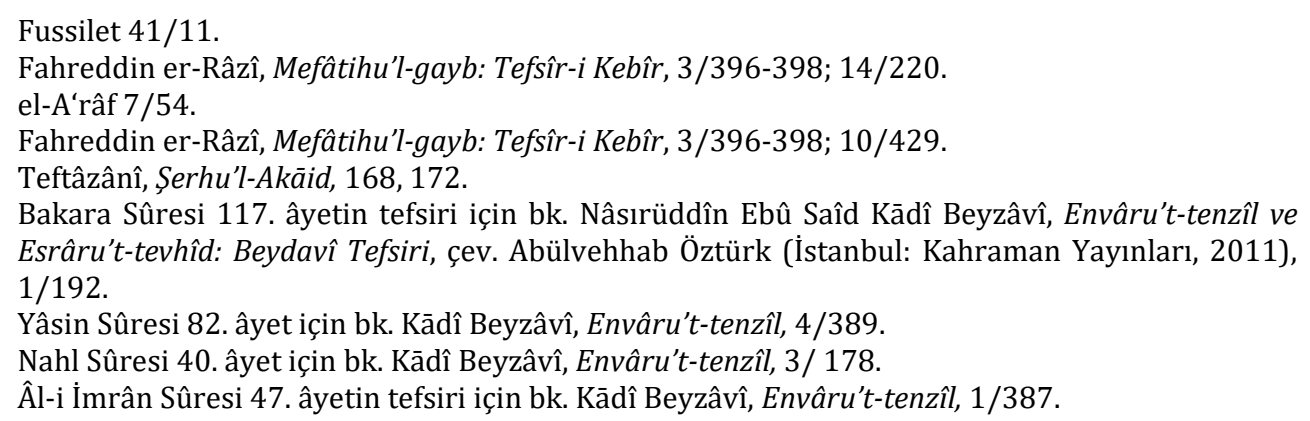


yaratmadaki hızını ifade eden mecazî bir ifade olduğu görüşüne yaklaşmışlardır. Ancak bu âlimlerin kün emri hakkındaki te'villerinin, Mâtürîdîlerden farklı olarak, mezhebin genel kanaati olan kudrete dayalı yaratma anlayışıyla çelişmeyecek bir biçimde ifade edildiği dikkati çeker. Nitekim Mâtürîdîlerin kün emrine dayalı te'villeri daha çok yaratmanın hızına yönelikken, Eş‘arî âlimlerinin te'villeri ise kün emrinin kudretle ilişkilendirilmesine yöneliktir. Bu bağlamda Eşarâi âlimlerinin kün emri hakkındaki te'vil yöntemini esas alan yorumlarında, mezhebin yaratmayı açıkladıkları ezelî sıfat olan kudret vurgusu daima muhafaza edilmiş; bu anlayış Mâtürîdîlerin tevil yönteminde olduğu gibi tekvin bahsine taşınmamıştır.

\section{Sonuç}

Semâvî dinler geleneğinde önemli bir yere sahip olan "söz-yaratma" ilişkisi, Kur'ân-ı Kerîm'de geçen "kün âyetleri" bağlamında ifadesini bulmuş ve kelâm mezhepleri kendi düşünce sistemleri çerçevesinde bu konuyu ele almışlardır. İlahiyyât bahisleri içerisinde bir taraftan âlemin yaratılması ve tekvin-mükevven ilişkisi, değer taraftan da Allah'ın kelâmı konusuyla bağlantılı olan "kün emri", geleneksel sünnî düşünceyle uyumlu bir kelâm anlayışı sergilemeye çalışan Eş'ariyye ile dengeli bir akılcı yöntem arayışı içerisinde olan Mâtürîdiyye arasındaki tartışmalı meselelerden biri olarak karşımıza çıkmaktadır. Kur'an'da sekiz âyette zikredilen ve Cenâb-ı Hakk'ın hem başlangıçta evreni yaratmasını hem de sonrasında tek tek nesneleri vücuda getirmesini tasvir eden "kün-feyekûn" ifadesini Selefî ve Küllâbî anlayışa göre değerlendiren Eş'arîler "ispat" yöntemini, konuya kelâmî bir perspektiften bakan Mâtürîdîler ise "te’vil” yöntemini esas almıştır. Bu bağlamda "kün" emri hakkında yaşanan tartışmaların arka planında sadece kudret-tekvin ihtilafı değil, aynı zamanda her iki mezhebin naslara yaklaşım tarzlarına dayalı bir yöntem farklılı̆̆ı bulunmaktadır.

Allah'ın bir şeyi yaratmak istediğinde ona “ol!” sözü ile emirde bulunması şeklindeki Kur'anî ifadeyi İmam Mâtürîdî ve onu takip eden talebeleri doğrudan temsili bir anlatım olarak te'vil etmişler. Onlara göre bu mecazî ifadelerin amacı, göz açıp kapayıncaya kadar gerçekleşen yaratma fiilinin Allah için ne kadar kolay ve zahmetsiz bir iş olduğunun muhataba kendi anlayacağı bir dille aktarılmasından ibarettir. Ebü'l-Muîn en-Nesefî'nin başını çektiği bir kısım bilginler ise "kün" emrini tekvin sıfatını hâdis kabul eden Eş'arîlerin bu görüşünü çürütmeye yönelik cedelî bir argüman olarak kullanmışlardır. Onlara göre yaratmaya esas teşkil eden kün sözü, şayet muhatapların iddia ettiği gibi ezelî ise kendisiyle yaratmanın gerçekleștiği bu nitelik tekvinden başkası olamaz. Dolayısıyla Eş'arîlerin, kudret sıfatına ilave bir nitelik olarak tekvini gereksiz gördükleri halde "kudretin varlığa taalluku" biçiminde ezelî bir kün emrinden söz etmeleri, aslında tekvini ispat anlamına gelmektedir. Çünkü kudret ve irade dışında mevcut olup, varlıkların meydana gelecekleri zamanda var olmalarını sağlayan (liyekün) ezelî sıfat tekvindir. Hanefî-Mâtürîdî gelenek içerisinde yer alan Pezdevî, Serahsî ve Saffâr gibi diğer bazı düşünürlere gelince, onlar daha muhafazakar ve nasçı (Selefî metod) bir tavır sergileyerek kün lafzını tekvin ile 
birlikte yaratmada etkisi bulunan ezelî bir söz olarak değerlendirmişlerdir. Böylece onların tekvini kabul etmek bakımından Mâtürîdîlere, kün emrinin ezelî kelâma delalet etmesi açısından yaratmada gerçek bir rolünün bulunduğu düşüncesiyle de Eş'arîlere yaklaşan eklektik bir tavır takındıkları görülür.

Pek çok kelâmî meselede Ehl-i hadis âlimlerinin görüşüne yaklaşarak nasların zahirlerine bağlı kalmayı ve te'vilden uzak durmayı tercih eden Eş'arî ve onun ilk dönemdeki takipçileri Kur'an'da zikredilen kün-feyekûn ifadesini, âlemin yaratıcı bir sözle yaratılması şeklinde zahiri üzere anlamışlardır. Onların bu yaklaşımı hem Selefin anlayışına hem de önceki semavî kitaplar geleneğine paralel görünse de kelâmî/aklî açıdan birtakım güçlük ve çelişkileri barındırır. Öncelikle yaratma ile yaratılan (tekvin-mükevven) ayrılığının mümkün olamayacağını beşerî fiiller gibi ilahî fiillerin de mefulüyle aynı zamanı paylaşması gerektiğini savunun ve bu sebeple Allah'ın fiillerinin ezelî olması durumunda yaratılmışların da ezelî olacağını ileri süren Eş'arîlerin, ilgili âyetlere dayanarak eşyanın ezelî kün sözüyle varlığa geldiğini söylemeleri oldukça tutarsız görünmektedir. Kendileri tarafından isabetli görülmeyen tekvin-mükevven (ezeli fiil-hâdis meful) ayırımının vahiy tarafından "kün-feyekûn" veya "emir-halk" gibi lafızlarla yapıldığını ileri sürmeleri de onların sistemini rasyonel yönünü tartışmalı hale getirmektedir.

Mâtürîdîler tarafından da dile getirilen söz konusu eleştiri karşısında Eş‘arîlerin: "Asıl yaratıcı sıfat kudrettir, kün ise kudretin taallukudur." şeklinde cevap vermeleri bir başka eleştiriyi gündeme getirir. Bu da kün emrinin ezelî kabul edildiği halde bir sıfatın taallukunun hâdis olması gerektiğidir. Yine onların "kün"ü ezelî söz kabul ederken emir, nehiy, haber ve istihbar gibi türevlerini ise onun farklı taallukları saymaları, bir anlamda "taallukun taalluku" olup olmayacağı sorusunu akla getirmektedir. Öte yandan kâf ve nûn harflerinden müteşekkil olan "kün" emrinin aynı zamanda Allah'ın kelâm sıfatına nispet edilip bu sıfata konuşma, mana aktarma ve iletişim gibi nitelikler dışında şahit âlemde kıyası mümkün olmayan "yaratma, eyleme" gibi başka bir yetkinliğin yüklenmesi kelâm sistemi açısından izahı güç pek çok problemi beraberinde getirmektedir.

$\mathrm{Bu}$ yaklaşımda harflerden müteşekkil lafzî kelâmın kadîm sayılması (ve Allah'a Arapça konuşma nispeti) bir tarafa konulsa bile, bir sıfatın (kelâm) kendisinin veya taallukunun (emir) başka bir sıfatın (kudret) taalluku gibi görülmesi, aynı fiili (yaratma) iki sıfatın paylaşması (kudret-kelâm), bir sıfatın (kelâm) tanımında yer almayan (mana olma ve emir, nehiy, haber bildirme) dışında başka bir ilahî yetkinliği (varlık verme) açıklamakta kullanılması vb. çelişkileri ihtiva etmesine rağmen Eş'arîler tarafından savunulmasının tek izahı, kanaatimizce nasların zâhirine ittiba gayesidir. Sonuç olarak kaynağını naslardan alan "yaratıcı söz teorisi”nin zayıflığı müteahhirin dönem Eş'arî bilginlerince fark edilmiş ve benzeri çoğu ihtilafta olduğu gibi İmam Mâtürîdî'nin rasyonel yaklaşımı doğrultusunda tashih edilmiştir. Ancak Mâtürîdî âlimlerinin te'vilinde kendi sistemlerine ters düşmeyecek şekilde ezeli yaratma ve tekvin anlayışı öne çıkarken bu bilginlerin yorumlarında ise mezhebin genel yaklaşımına uygun olarak hâdis yaratmanın ilkesi olan ezeli kudrete atıf söz 
konusudur. Sonuç itibariyle kün emrinin metafizik bir kavram olan ve görünür evrene kıyasla anlaşılması imkânı bulunmayan "yaratma" hadisesinin temsilî ve mecazî bir anlatımı şeklinde değerlendirilmesi bize göre de en isabetli yaklaşım tarzı olarak görünmektedir.

\section{Kaynakça}

Ali el-Kārî. Fıkh-ı Ekber Şerhi. çev. Hüseyin S. Erdoğan. İstanbul: Hisar Yayınevi, ts.

Ahmed b. Hanbel, Ebû Abdillâh Ahmed eş-Şeybânî. er-Red ale'l-Cehmiyye ve'z-Zenâdika. thk. Sabri b. Selâme Şahin. Riyad: Dâru's-Sebât, 2003.

Âmidî, Seyfeddin. Gāyetü'l-merâm fí ilmi'l-kelâm. nşr. Hasan Mahmûd Abdüllatif. Kahire: Vizaretü'l-Evkāf, 1971.

Avcu, Ali. Horasan-Maveraünnehir'de İsmailîlik. İstanbul: Marmara Akademi Yayınları, 2018.

Aykaç, Mustafa. “Osmanlı Kelâmında Mâtürîdilik Vurgusu: Şerhu'l-Akâid Hâşiyelerindeki Tekvin Tartışmaları Bağlamında Bir İnceleme”. KADER 18/1 (Haziran 2020), 1-30.

Bağdâdî, Abdulkāhir. el-Fark beyne'l-firak: Mezhepler Arasındaki Farklar. çev. Ethem Ruhi Fığlalı. Ankara: Türkiye Diyanet Vakfi, 1991.

Bağdâdî, Abdülkāhir. Usûlü'd-din. thk. Ahmed Şemsüddin. Beyrut: Dârü'l-Kütübi'l-İlmiyye, 2002.

Bâkıllânî, Ebû Bekr. Temhîdü'l-evâil ve telhisü'd-delâil. thk. Mektebetü'l-İlmî. Beyrut: Müessesetü'l-Kütübi's-Sekafiyy, 2016.

Bâkıllânî, Ebû Bekr. el-İnsâf fîmâ yecibu i'tikāduhu velâ yecûzü'l-cehl bihi. thk. Muhammed Zâhid el-Kevserî. Kahire: Mektebetü'l-Ezheriyyeti li't-Turâs, 2. Basım, 2000.

Beyâzîzâde, Ahmed Efendi. İşâratü'l-merâm min ibârâti'l-imâm. thk. Ahmed Ferîd el-Mezîdî. Beyrut: Darü'l-Kütübi'l-İlmiyye, 2007.

Beyhakî, Ebû Bekr Ahmed. el-Esmâ ve'sıfat. 2 Cilt. Beyrut: Dâru'l-Kütübi'l-İlmiyye, 1998.

Beyhakî, Ebû Bekr Ahmed. "Kitâbü'l-İ'tikād ve'l-hidâye". el-Mesâilü'l-Ihhtilâf beyne'l-Eşâira ve'lMâtürîdiyye. mlf. Şemseddin İbn Kemal Paşa. thk. Saîd Abdullatif Fûde. 137-179. Amman: Darü'l-Feth li'd-Dirâsâti ve'n-Neşr, 2009.

Buhârî, Muhammed b. İsmail. Halku ef'âli'l-'ibâd: İlahî Kelâmın Müdafaası. çev. Yusuf Özbek. İstanbul: İz Yayıncılık, 2019.

Cürcânî, Seyyid Şerif. Şerhu'l-Mevâkıf. çev. Ömer Türker. 3 Cilt. Ankara: Türkiye Yazma Eserler Kurumu Başkanlı̆̆ı, 2015.

Cüveynî, İmâmü'l-Haremeyn. Kitâbü'l-İrşâd: İnanç Esasları Kılavuzu. çev. Adnan Bülent Baloğlu vd. Ankara: Türk Diyanet Vakfı Basımevi, 2016.

Çağrıcı, Mustafa. "İbn Meserre". Türkiye Diyanet Vakfi İslâm Ansiklopedisi. 20/188-193. İstanbul: TDV Yayınları, 1999.

Dârimî, Ebû Saîd. er-Red ale'l-Cehmiyye. Kuveyt: Dâru's-Selefiyye, 1985.

Ebû Azbe, Hasen b. Abdilmuhsin. Ravzatu'l-behiyye fî mâ beyne'l-Eşâira ve'l-Mâtürîdiyye. Haydarabad: Dâiretü'l-Maârifi'n-Nizâmiyye, 1322.

Ebû Hanîfe, Nu'man b. Sâbit. "Vasiyyetü'l-İmâm Ebî Hanîfe", İmam-ı Azam'ın Beş Eseri. çev. Mustafa Öz. İstanbul: MÜIFAV Yayınları, 1992.

Ebstein, Michael. Mysticism and philosophy in al-Andalus: Ibn Masarra, Ibn al-Arabi and the Ismaili tradition. Leiden: E.J. Brill, 2013.

Eş'arî, Ebü'l-Hasan Alî b. İsmâîl b. Ebî Bişr. el-İbâne an usûli'd-diyâne. thk. Abbâs Sabbăg. Beyrut: Dâru'n-Nefâis, 1994. 
Eş'arî, Ebü'l-Hasan Alî b. İsmâîl b. Ebî Bişr. el-Lüma' fi'r-red alâ ehli'z-zeyğ ve'l-bida': Eş'arî Kelâmı. çev. Kılıç Aslan Mavil - Hikmet Yağlı Mavil. İstanbul: İz Yayıncılık, 2016.

Eş'arî, Ebü'l-Hasan Alî b. İsmâîl b. Ebî Bişr. Makālâtü'l-İ́slâmiyyîn ve İhtilâfü'l-musallîn: İlk Dönem İslam Mezhepleri. çev. Mehmet Dalkılıç - Ömer Aydın. İstanbul: Kabalcı Yayınevi, 2005.

Eş'arî, Ebü’l-Hasan Alî b. İsmâîl b. Ebî Bişr. Usûlü Ehli's-sünne ve'l-cemâa. thk. Muhammed Seyyid el-Celyend. Kahire: Mektebetü'l-Ezheriyye li't-Turâs, 2013.

Fahreddîn er-Râzî, Ebû Abdillâh Fahrüddîn Muhammed. Tefsîr-i Kebîr: Mefâtihu'l-gayb. çev. Lütfullah Cebeci vd. 18 Cilt. İstanbul: Huzur Yayınevi, 2002.

Fahreddîn er-Râzî, Ebû Abdillâh Fahrüddîn Muhammed. Me'âlimü usûli'd-dîn: Kelâm İlminin Esasları. çev. Muhammet Altaytaş. İstanbul: Türkiye Yazma Eserler Kurumu Başkanlığı, 2019.

Fahreddîn er-Râzî, Ebû Abdillâh Fahrüddîn Muhammed. el-Muhassal: Ana Meseleleriyle Kelam ve Felsefe. çev. Eşref Altaş. İstanbul: Klasik Yayınları, 2. Basım, 2019.

Fahreddîn er-Râzî, Ebû Abdillâh Fahrüddîn Muhammed. Halku'l-Kur'ân beyne'l-Mu'tezile ve Ehlü's-sünne. thk. Ahmed Hicâzî es-Sekkâ. Beyrut: Dârü'l-Cîl, 1992.

Fahreddîn er-Râzî, Ebû Abdillâh Fahrüddîn Muhammed. Muhassalu efkâri' '-mütekaddimîn ve'lmüteahhirîn mine'l-ulemâ. thk. Tâhâ Abdurraûf Sa'd. Kahire: Mektebetü'l-Külliyati'lEzheriyye, ts.

Gazzâlî, Ebû Hâmid. el-İktisâd fi'l-İtikād: itikatta Orta Yol. çev. Ömer Dönmez. İstanbul: Hisar Yayınevi, ts.

Gazzâlî. Ebû Hâmid. İhyâu ulûmi'd-dîn. çev. Ahmed Serdaroğlu. 4 Cilt. İstanbul: Bedir Yayınevi, 2002.

Gazzâlî, Ebû Hâmid. "el-Kânûn külli fi't-te'vîl: Gazzâlî'nin Te'vil Hakkında Basılmamış Bir Eseri”. çev. Mehmed Şerefeddin. Darülfünun Illahiyat Fakültesi Mecmuası 4/16 (193), 46-58.

Gazzâlî, Ebû Hâmid. Faysalu't-tefrika beyne'l-İslâm ve'z-Zenâdıka: İslam'da Müsmaha. çev. Süleyman Uludağ. İstanbul: Dergâh Yayınları, 2016.

İbn Fûrek, Ebû Bekr Muhammed b. el-Hasen. Mücerredü Makālâti'ş-Şeyh Ebi'l-Hasan el-Eş'arî. thk. Daniel Gimaret. Beyrut: Dârü'l-Meşrik, 1987.

İbn Kuteybe, Ebû Muhammed Abdullah b. Müslim. el-Maârif. thk. Servet Ukkâş̧e. Kâhire: Dâru'l-Maârif, ty.

İbn Teymiyye, Takiyyüddîn Ahmed. Mecmû'u fetâvâ: Kitâbü'l-Kur'ân. thk. Âmir Cezzâr - Enver Baz. 12. Cilt. b.y., t.y.

İbnü'l-Arabî, Muhyiddîn. Fütûhât-ı Mekkiyye. çev. Ekrem Demirli. 2. Cilt. İstanbul: Litera Yayıncllık, 2007.

Kādî Abdülcebbâr, Ebü'l-Hasen Kādı'l-kudât. el-Muğnîfî ebvâbi't-tevhîd ve'l-adl: Halku'l-Kurân. thk. Taha Huseyn, İbrahim el- Ebyârî. 7. Cilt. Kahire: b.y., 1380/1960.

Kādî Abdülcebbâr, Ebü'l-Hasen Kādı'l-kudât. Şerhu'l-Usûli'l-hamse: Mu'tezile'nin Beş İlkesi (Mu'tezile'nin Beş Esasının Açılımı). çev. İlyas Çelebi. 2 Cilt. İstanbul: Türkiye Yazma Eserler Kurumu Başkanlığı, 2013.

Kādî Beyzâvî, Nâsırüddîn Ebû Saîd. Tavâli'u'l-Envâr: Kelâm Metafiziğii. çev. İlyas Çelebi Mahmut Çınar. İstanbul: Türkiye Yazma Eserler Kurumu Başkanlığı, 2014.

Kādî Beyzâvî, Nâsırüddîn Ebû Saîd. Envâru't-tenzîl ve Esrâru't-tevhîd: Beydavî Tefsiri. çev. Abülvehhab Öztürk. 5 Cilt. İstanbul: Kahraman Yayınları, 2011. 
Kaya, Emrah. "Sonsuz Tecellî ve Daimî Yaratma: İbn 'Arabî ve İbn Teymiyye'nin Yaratma Meselesine Ezelî Fiil Olarak Bakışı”. Ankara Üniversitesi Illahiyat Fakültesi Dergisi 57/2 (2016), 69-96.

Kemalpaşazade, İbn Kemal Ahmed Şemseddin. Mesâilü'l-ihtilâf beyne'l-Eşấira ve'lMâtüridiyye, thk. Saîd Abdullatif Fûde. Amman: Dâru'l-Feth lid'd-Dirâsâti ve'n-Neşr, 2009.

Kılıç, Mahmut Erol. “İbnü’l-Arabî, Tasavvuf”, Türkiye Diyanet Vakfı İslâm Ansiklopedisi. 20/493516. İstanbul: TDV Yayınları, 1999.

Kitabı Mukaddes. İstanbul: Kitabı Mukaddes Șirketi, 2003.

Lâmişî, Ebu's-Senâ. Kitâbü't-Temhid li-kavâ'idi't-tevhîd. thk. Abdülmecid Türkî. Beyrut: Dârü'lGarbi'l-İslâmî, 1995.

Mâtürîdî, Ebû Mansûr. Kitâbü't-Tevhîd Tercümesi. çev. Bekir Topaloğlu. Ankara: İSAM Yayınları, 2002.

Mâtürîdî, Ebû Mansûr. Te'vîlâtü'l-Kur'ân. thk. Mustafa Yavuz, 17 Cilt. İstanbul: Mizan Yayınevi, 2005-2010.

Nesefî, Ebü'l-Berekāt. Tefsîrü'n-Nesefí: Medâriku'l-tenzîl ve hakāiku't-te'vîl. thk. Yusuf Ali Bedevî. 3 Cilt. Beyrut: Dâru'l-Kelimeti't-Tayyib, 1998.

Nesefî, Ebü'l-Mu'în. Tebsıratü'l-edille. thk. Hüseyin Atay. 2 Cilt. Ankara: Diyanet İşleri Başkanlığı, 1993.

Nesefî, Ebü'l-Muîn. Kitâbü't-Temhîd li kavâidi't-tevhîd: Tevhidin Esasları. çev. Hülya Alper. İstanbul: İz Yayıncllık, 2017.

Nesefî, Necmeddin Ömer. et-Teysîr fi't-tefsîr: Ömer Nesefí Tefsiri. çev. Ali Benli. 2 Cilt. İstanbul: Türkiye Yazma Eserler Kurumu Başkanlığı, 2020.

Nokta Sembolizmi: Noktatül'-Beyân Risâlesi. nşr. Mehmet Tabakoğlu - Şükrü Maden. İstanbul: İnsan Yayınları, 2020.

Özgen, Mustafa. Eş'arî ve Mâtürîdî Mezhepleri Arasındaki Görüş Farklılıkları. Konya: Palet Yayınları, 2017.

Öztürk, Mustafa. Kur'an ve Yaratılış. İstanbul: KURAMER Yayınları, 2017.

Öztürk, Yunus. "Hanefî-Mâtürîdî Geleneğin Mutasavvıf Bir Müellifi Ve Mesnevî Türü Eseri Olarak Âşılk Paşa Ve Garibnâme Üzerine Karşılaştırmalı Bir Analiz". Sünni-İrfani Geleneğin 14. Yüzyıl Temsilcisi Âşsk Paşa ve Türkçe Mesnevisi Garibnâme Üzerine İncelemeler. ed. Yunus Öztürk. 141-171. İstanbul: Ensar Neşriyat, 2020.

Pala, İskender. "Kün". Türkiye Diyanet Vakfi İslâm Ansiklopedisi. 26/552-553. Ankara: TDV Yayınları, 2002.

Pezdevî, Ebü'l-Yüsr. Ehl-i Sünnet Akâidi. çev. Şerafeddin Gölcük. İstanbul: Kayıhan Yayınları, 3. Basım, 1994.

Sâbûnî, Nûreddîn. el-Kifâye fi'l-hidâye. thk. Muhammed Arûçi. İstanbul: İSAM Yayınları, 2014.

Sâbûnî, Nûreddîn. el-Bidâye fí usûli'd-dîn: Mâtürîdiyye Akâidi. çev. Bekir Topaloğlu. Ankara: DİB Yayınları, 1995.

Sâlimî, Ebû Șekûr. et-Temhîd fi beyâni't-tevhîd. thk. Ömür Türkmen. İstanbul: İSAM Yayınları; Beyrut: Dâru İbn Hazm.

Saffâr, Ebû İshâk. Telhîsü'l-edille li-kavâidi't-tevhîd. thk. Angelika Brodersen. 2 Cilt. Beyrut: elMa'hedü'l-Almani li'l-Ebhâsi'ş-Şarkiyye, 2011.

Serahsî, Ebû Bekr Şemsüleimme. Usûlü's-Serahsî. thk. Ebü'l-Vefâ el-Efgânî. 2 Cilt. Kahire: Dârü'l-Kitâbi'l-Arabi, 1954.

Siğnâkî, Hüsâmüddîn Hüseyn b. Alî b. Haccâc. Kitâbü't-Tesdîd fî şerhi't-temhîd li'l-Siğnaki. thk. Şemseddin Kerim. Almatı: Matbaatü Nur Mübarek, 2016. 
Sinanoğlu, Mustafa. "Logos". Türkiye Diyanet Vakfi İslâm Ansiklopedisi. 25/212-214. Ankara: TDV Yayınları, 2002.

Şehristânî, Ebü'l-Feth Abdülkerim. Milel ve Nihal: Dinler, Mezhepler ve Felsefí Sistemler Tarihi. çev. Mustafa Öz. İstanbul: Litera Yayıncılık, 2008.

Şehristânî, Ebü'l-Feth Abdülkerîm. Nihâyetü'l-ikdâm. thk. Alfred Guillaume. London: Oxford University, 1934.

Şeyhzâde, Abdürrahim b. Ali. Nazmu'l-ferâid ve cem'u'l-fevâid. Mısır: Matbaatü'l-Edebiyye, 1317.

Teftâzânî, Sa'deddîn. el-Makāsıdu'l-kelâm fí 'akāidi'l-İslâm: Kelâm İlminin Maksatları. çev. İrfan Eyibil. İstanbul: Türkiye Yazma Eserler Kurumu Başkanlığı, 2019.

Teftâzânî, Sa'deddîn. Şerhu'l-Akāid: Kelâm İlmi ve İslâm Akâidi. çev. Süleyman Uludağ. İstanbul: Dergâh Yayınları, 4. Basım, 1999.

Yağlı Mavil, Hikmet. "Ehl-i Sünnet Kelâmında Halku'l-Îmân Tartışması". AİBÜ İlahiyat Fakültesi Dergisi 7/14 (2019), 437-468.

Yeşilyurt, Temel. "Maturidilerde Tekvin Sıfatı ve Temellendirilmesi". KÜIFD 1/1 (2017/1), 923.

Yıldırım, Ömer Ali. “İslam Düşüncesindeki Yoktan Yaratma ve Kıdem Tartışmaları: Kelâmcılar ve İbn Sîna Merkezli Bir İnceleme”, Kelam Araştırmaları Dergisi [Kader] 10/2 (2012), 251-274.

Yücedoğru, Tevfik. Geçmişten Günümüze Doğru İlim ve Din Açısından Yaratılış. Bursa: Emin Yayınları, 2006.

Zemahşerî, Ebü'l-Kāsım. el-Keşşâf'an hakāikı ğavâmid't-tenzîl ve 'uyûni'l-ekāvîl fî vucûhi'-Te'vîl: Keşşâf Tefsiri. çev. Muhammed Coşkun vd. 6 Cilt. İstanbul: Türkiye Yazma Eserler Kurumu Başkanlığı, 2016-2020. 